\title{
Do Incumbents Manipulate Access to Finance During Banking Crises?
}

\author{
Erik Feijen*
}

\begin{abstract}
This paper tests the hypothesis that during systemic banking crises, access to finance is opportunistically tightened by incumbents to eliminate or weaken competition from mainly young firms. We find this to be especially true in more corrupt countries. To do so, we employ a methodology similar to Rajan and Zingales (1998) on three digit manufacturing industry-level data provided by the United Nations Statistics Division for about 15 developed and developing countries in over 20 industries on average. We show that price-cost margins in externally more financially dependent industries are higher during crisis than in externally less dependent industries in countries with higher levels of corruption. We find the opposite relationship for the change in the industry-level number of establishments during a crisis. The results withstand an array of robustness checks, including using different indices of corruption, different controls, and robust estimation techniques.
\end{abstract}

JEL Classifications: D73, G1, G2, G3, and P48.

Keywords: Access to Finance; Systemic Banking Crises; Corruption.

World Bank Policy Research Working Paper 3660, July 2005

The Policy Research Working Paper Series disseminates the findings of work in progress to encourage the exchange of ideas about development issues. An objective of the series is to get the findings out quickly, even if the presentations are less than fully polished. The papers carry the names of the authors and should be cited accordingly. The findings, interpretations, and conclusions expressed in this paper are entirely those of the authors. They do not necessarily represent the view of the World Bank, its Executive Directors, or the countries they represent. Policy Research Working Papers are available online at http://econ.worldbank.org.

* University of Amsterdam and World Bank. Email: e.h.b.feijen@uva.nl. I thank the World Bank’s Financial Sector Operations and Policy Department for its hospitality while this paper was written. Without implication, I would like to thank the following people. Stijn Claessens, Rocco Huang, Luc Laeven, Enrico Perotti, Ernesto Revilla, and Konstantinos Tzioumis for detailed discussions and/or comments on earlier drafts. Furthermore, I appreciate useful comments and suggestions of participants during the conference on Endogenous Institutional Change at Stanford, March 2005. 
This paper studies the effect of corruption on access to finance and its impact in times of systemic banking crises on the real sector. It asks the basic question: do incumbents try to curtail access to external finance for their competitors during systemic banking crises? Indeed, the paper empirically identifies access to finance as a likely candidate which incumbents may manipulate to "starve" their weaker competitors from credit during a crisis to safeguard their own rents. Hence this paper adds to the relatively small body of empirical literature on mechanisms through which access to finance affects real activity during financial crises. More specifically, it identifies an explicit "political economy of finance" channel through which special interests distort the level-playing field during crises. Furthermore, to the extent that the politics of incumbent rents affect the economic growth trajectory of a country, the results support the findings of the finance and growth literature and reconfirm the large literature which attests to the first order importance of institutions on economic development.

The basic idea originates from the theoretical model in Feijen and Perotti (2005) where rich entrepreneurs lobby politicians to restrict access to finance for poor entrepreneurs in bad economic times. It builds a model where all agents have identical, positive net present value projects and are all subject to an economy-wide exogenous shock with a certain probability. Agents have either high or low endowment (i.e., are rich or poor). In the event of a shock, all agents need to raise extra immediate funds externally. If they are unable to do so, they are forced to default inefficiently. Given the probability of a shock, the model predicts that rich entrepreneurs in countries with poor political checks and balances are more likely to lobby ex ante for lower investor protection. The motive is that in a context of low investor protection, poorer, more highly 
leveraged entrepreneurs are denied the extra funds in case of a shock and are forced to exit the market, which raises the rents of the rich during a decrease in competition. In this paper, we test the general interpretation of this model: when outright denial of ex ante finance for entrants is impossible or too costly, connected firms will lobby for a fragile financial system which leads to a reduction of competition during an exogenous shock, like a banking crisis.

To empirically test whether lobbying over access to finance is used by incumbents to reduce competition, we need a proxy to assess the effect of their ability to affect access to finance, thereby keeping their profits high. For this purpose, we interpret the change of the industry-level average Lerner index or price-cost margin (henceforth PCM) during a systemic banking crisis as a measure of profitability of "strong", incumbent firms, which are most likely to withstand a crisis because they are well-connected. We are not the first one to analyze PCMs as a measure of (political) strength. Also Braun and Raddatz (2005) interpret change in PCMs during trade liberalization as a proxy for shift in the incumbent's political and economic power.

In the same spirit, we interpret fewer number of establishments (henceforth EST) during a crisis as more beneficial to incumbent or "strong" firms. Others also have analyzed the number of establishments of the data we use (see Rajan and Zingales, 1998; Claessens and Laeven, 2003; Fisman and Sarria-Allende, 2004; Perotti and Volpin, 2004).

We analyze the changes in PCM and EST associated with systemic banking crises across industries in both developed and developing countries. Industry-level PCMs are defined as total net profit over value of total output and are traditionally interpreted as a measure of incumbent monopoly rents and an inverse proxy for the degree of competition 
in an industry. Theoretically, the PCM can range from zero to one, where a value of zero indicates an industry described by perfect competition. A value of one represents a pure monopolistic industry structure. However, in practice one needs to be a bit careful in interpreting PCMs as proxies for monopoly power, since the Lerner Index of monopoly power is calculated using marginal, not average costs and assumes the industry is in equilibrium. This is not too worrisome since we only need to interpret the PCM as a proxy for the average profitability in the industry.

How does a systemic banking crisis affect the industry PCMs? ${ }^{1}$ The adverse shock of a crisis increases the need for immediate capital because of, for example, possibly soaring input prices, an increasing interest burden on debt or banks that try to call in their outstanding loans due to their own liquidity constraints. Worse, the subsequent drying up of credit markets, a typical consequence of banking crises, could make firms even more tightly liquidity constrained, forcing them either to default, resulting in a reduction of the EST, or to downsize output substantially because of a shortage of working capital. This is exacerbated in most emerging markets, since bank lending is the most prevalent form of external finance. Indeed, Claessens, Djankov, and Ferri (1999) estimate that about 30 percent of corporations in crisis-affected East Asian countries were insolvent in the fall of 1998. More than twice as many firms in these countries suffered illiquidity. This results in a reduction of total output, which may have a positive effect on the PCM via upward pressure on prices, ceteris paribus.

Incumbents benefit relatively more from a high PCM and a decrease in the EST. These "strong" firms have close ties with politicians and banks. Claessens et al. (2003) document that significantly fewer firms that were affiliated with firm groups or banks filed for bankruptcy, suggesting their connections provided them with the (financial) 
means necessary to weather the crisis. Faccio (2004) finds that strong connections between firms and politicians are particularly common for large firms in countries that are generally perceived as being highly corrupt. She finds that businesspeople entering politics has a positive effect on the stock value of the associated companies. Fisman (2001) shows that the stock value of politically connected firms in Suharto's Indonesia declined more when adverse rumors circulated about the health of the president.

In addition, we assume "strong" firms are able and willing to press investors, notably banks, to make access to finance for "weak" firms more difficult in terms of rates and volume. The incentive to do so should be always present, but is even higher during a crisis when "weak" competitors are financially most vulnerable. Furthermore, we assume that average costs of "strong" firms do not increase relative to their "weaker" competitors. Again, we expect this is largely, but certainly not exclusively, due to the access to finance channel. For example, economies of scale, bribing or usage of political connections of "stronger" firms to pursue different channels to reach their goals could also adversely affect the change in relative average costs for "weaker" firms during crises. Demand changes during a crisis equally affect "strong" and "weak" firms, so if these assumptions are satisfied, higher industry-level PCMs during crises benefit "strong" firms more - or hurt them less - relative to "weak" firms.

An analogous story can be told for the interpretation of the EST. If there is a significant decrease in the EST during a crisis, it is most likely that "weak" firms have left the market, which diminishes competition for "strong" firms.

Under these assumptions, the main idea put forth in this paper is as follows. "Strong", connected firms in industries where young firms are more dependent on external finance will be relatively more profitable during banking crises. Empirically, this 
implies that in more corrupt countries during systemic banking crises, industries where young firms are more dependent on external finance experience:

- Hypothesis 1: higher price-cost margins (PCMs).

- Hypothesis 2: fewer number of establishments (EST).

We find that the data support these hypotheses, even after performing an array of robustness checks. To consider the effect of the hypotheses, we use the regression coefficients to predict what the PCM difference would be between high dependent and less dependent industries for a high and a low corrupt country. This difference is relatively larger in more corrupt countries. The regression models predict that the difference in PCM change between a high and low dependent industry - the $75^{\text {th }}$ and $25^{\text {th }}$ percentile - to be 2.9 percent lower in a less corrupt country - taken at the $75^{\text {th }}$ percentile - compared to a high corrupt country - taken at the $25^{\text {th }}$ percentile (note that a higher corruption index means less corruption). For comparison, the average relative PCM change for the universe of calculated PCM changes is 5 percent. Therefore, a differential change of -2.9 percent due to an improvement in the corruption index from 3 to 4.1 represents a large decrease. A similar analysis yields that the relative change in EST is 2.1 percent higher due to an improvement in the corruption index from the $25^{\text {th }}$ to the $75^{\text {th }}$ percentile. Given that the average relative EST change during crisis is -5.2 percent, this a large increase.

In addition, by adopting quantile regression techniques, we find that the effect of Hypothesis 1 is non-linear and is substantially magnified in those countries with very high levels of corruption.

Interestingly, in the robustness checks, we find that PCMs in industries which are more "opaque", i.e. divulge less information via prices in the stock market, have 
relatively higher PCMs and less EST in countries which are more corrupt. This finding suggests that a "smoke screen" encourages manipulation to weaken competitors.

Furthermore, there is a strong indication that the regressions do not suffer from endogeneity problems. There are at least two reasons. First, we use pre-crisis explanatory variables. Second, intuitively, it seems quite unlikely that the dependent variable has a direct contemporaneous effect on the level of corruption, since we know that institutions do not vary substantially over time or will only do so with large lags (Acemoglu, Johnson, and Robinson (2001)).

A few remarks on the limitations of the results are in order. Besides the reliability of the data and the possible distortions which arise from a lack of data availability, the methodology leaves some questions unanswered. For instance, the data only allow us to treat the relationship between access to finance and corruption as a "black box": we cannot infer how corruption affects access to finance. Furthermore, we are unable to infer whether the reduction in competition is welfare decreasing. For example, the data do not directly tell whether exiting or shrinking of some bad performing firms is actually welfare improving. Moreover, an industry with higher rents for firms can be welfare improving since it will have enough net worth to be less conducive to risk shifting incentives. Also, we are not able to assess the extent to which banks initiate the effect. In theory, banks may have strong incentives to deny access to credit to weaker, but otherwise healthy firms during banking crisis to artificially diminish competition and enhance the present value of their other outstanding loans in the industry. This is arguably easier to accomplish in countries with high corruption.

The rest of the paper is structured as follows. Section I reviews the related literature and Section II explains the methodology used. Section III describes the data and 
Section IV presents the main results. Section V presents the robustness checks of the main results and Section VI concludes.

\section{Related literature}

In this section we describe several parts of the economic literature relevant for this paper. Thus far, the literature has not paid much attention to the intersection of the real impact of crises, institutions, and access to finance. Therefore this paper is related to several parts of the finance literature. First, there is the literature which focuses on the relationship between institutions, financial development and economic growth. Its finance and growth strand has empirically established the connection between financial development and economic growth (King and Levine, 1993; Jayratne and Strahan, 1996; Levine and Zervos, 1998; Rajan and Zingales, 1998; Beck, Levine and Loayza, 2000; Levine, 2005). More financially developed systems allow easier access to external finance by, for example, alleviating moral hazard and adverse selection problems, enabling firms to grow faster. Access to finance alone is not enough. Johnson et al. (2002) show in a study on firms in post-communist countries that even thought bank loans are available, firms are reluctant to reinvest when property rights are weak. Braun and Raddatz (2005) offer a political economy view on financial development. They find that countries that liberalized their trade subsequently improved in terms of their financial development if the difference in change due to the liberalization of the average PCM of industries that benefited from liberalization was larger than that of industries that suffered from it. Also relevant is the law and finance strand, which established the link between the quality of the institutional framework and the development of the financial sector ( $\mathrm{La}$ 
Porta et al., 1997; La Porta et al. 1998; Demirgüç-Kunt and Maksimovic, 1998; and Beck et al., 2003).

Second, there is a growing theoretical and empirical literature which documents or provides indirect evidence how political and economical elites use institutions to serve their own interests, often at the expense of competitors and social welfare. There is the general barriers to entry strand. Djankov et al. (2002) find that countries with higher corruption and larger unofficial economies tend to have higher barriers to entry as measured in terms of start up costs, number of procedures, etc. Their evidence is consistent with the view that these regulations primarily serve bureaucrats and politicians. Laeven, Klapper and Rajan (2004) document that entry regulations are associated with less efficient older firms and do not seem to be social welfare improving. He, Morck, and Yeung (2000) suggest that political rent-seeking by large established firms, especially in countries with fewer creditor rights, explains the relative stability in the list of countries' top firms which is associated with slower economic growth. As already mentioned, Fisman (2001) shows that the stock value of politically connected firms in Suharto's Indonesia declined more when adverse rumors circulated about the health of the president. Then there is the strand which focuses specifically on barriers to access to finance. Rajan and Zingales (2003) hypothesize that incumbents have incentives to oppose financial development because it breeds competition, hence eroding their rents. Perotti and Volpin (2004) describe a model in which rich entrepreneurs lobby politicians for poor minority protection to exclude product market competition of the poor because they cannot raise sufficient funds to undertake a project. Indeed they find some empirical support for their model. Cetorelli and Strahan (2004) document empirical evidence that in markets with few banks, entrants face greater difficulty in getting access to finance than 
in markets where banks are more competitive. Beck, Demirguc-Kunt, and Maksimovic (2004) also report that high banking concentration is associated with higher financial barriers to entry, especially for small firms. Haber (2004) provides anecdotal support for the conjecture that the fast growth of the $19^{\text {th }}$ century Brazilian textile industry was associated with a less concentrated banking system, while the concentrated banking system in Mexico, characterized by connected lending, probably inhibited growth in this industry. Finally, there is the strand on connected lending which is relevant. In particular one finds excessive, socially harmful related lending in countries with poor institutions. Loans to political or industrial connections are subsidized and often turn out to be nonperforming. La Porta et al. (2002) find such evidence in Mexico, Laeven (2001) in Russia, and Kwaja and Mian (2004) in Pakistan.

Third, there is a large crisis literature. Banking crises seem to hamper growth of financially dependent industries. Laeven, Klingebiel, and Krozner (2002) document empirical evidence that industries which are more reliant on external finance grow slower as a result of banking crises in countries which are more financially developed, suggesting that access to finance in crises indeed is important. In addition, political and economic elites have an incentive to shift the burden of crises or at least suffer less from it, possibly magnifying the detrimental effects of the crisis in the process. Keefer (undated) builds a model where favors between special interests and politicians make the economy less resilient to external shocks and can lead to a financial crisis. Empirically, he finds that these factors largely explain the fiscal costs of a crisis. Halac and Schmukler (2003) find that in Latin America higher income classes did particularly better at the expense of social welfare due to financial transfers from banks during banking crises. Johnson and Mitton (2001) provide empirical evidence that the imposition of the 
September 1998 Malaysian capital controls during the Asian financial crises benefited primarily firms with strong connections to Prime Minister Mahathir. Johnson et al. (1999) present empirical support that bad corporate governance, specifically a lack of minority shareholder protection, explains stock market declines better than the usual macroeconomic variables. They hypothesize that the drop in asset prices is because managers have larger expropriation incentives during a crisis.

\section{Methodology}

This section discusses the econometric methodology. We expand the methodology used in Rajan and Zingales (1998, RZ henceforth), which assesses the relationship between the cross-country real growth of sectoral value added and the level of sophistication of the financial system. Their main hypothesis is that if access to finance is paramount for firm growth, then real added value of industries which inherently rely more heavily on external finance should grow faster in countries with better developed financial systems. To curb identification problems and the criticism of omitted variable bias or model specification, they interact a country-specific variable (a proxy for the level of financial development) with an industry-specific variable (a proxy for dependence on external finance) besides using country- and industry-fixed effects in their regressions. To control for growth differences of industries across countries they use sectoral value added as a fraction of total value added in a country in 1980. A crucial assumption made by RZ is that industries in all countries have a natural external dependence level in common. They calculate this level by using industries in the United States as a benchmark. The rationale

to use the United States is that, because its financial system is open and relatively 
frictionless, it is easy for US firms to attain their desired financial structure. To overcome potential endogeneity problems, they drop the United States from the regressions. RZ find a positive and significant sign for the interaction between the level of financial development in a country and the industry-specific need for external finance, which supports their hypothesis: higher financial development indeed spurs industry growth more in industries which are more dependent on external finance.

First, we expand the RZ methodology to construct:

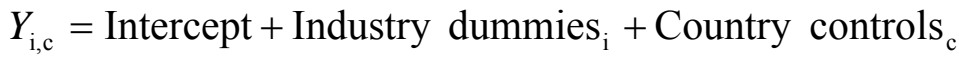

$$
\begin{aligned}
& +\beta_{1} \cdot \text { Pre - crisis level } Y_{\mathrm{i}, \mathrm{c}} \\
& +\beta_{2} \cdot \text { External dependence }_{\mathrm{i}} \cdot \text { Pre - crisis institution index }{ }_{\mathrm{c}} \\
& +\varepsilon_{i, c} \text {, }
\end{aligned}
$$

where subscript $i$ indicates industries and subscript $c$ countries in the database which experienced a systemic banking crisis. The dependent variable of interest, $Y_{\mathrm{i}, \mathrm{c}}$, is either the relative change of the industry-level PCM (DPCMREL) or the EST (DESTREL) during a crisis. To do so, we calculate the average industry PCM (EST) in the pre-crisis period and the crisis period. We define the pre-crisis period to be $[t-8, t-3]$ and the crisis period as $[t-1, t+1]$, where $t$ is the first year of the first systemic banking crisis, as indicated by Caprio and Klingebiel (2003). Here I closely follow Laeven, Klingebiel, and Krozner (2005). They choose the pre-crisis period to end two years before the first date of the first crisis as reported in Caprio and Klingebiel (2003) to ensure the calculations are not contaminated by the build-up towards the crisis. The crisis period is chosen around the first crisis date, because exact identification of the start of the crisis is difficult. 
The relative changes are derived from DPCMREL $L_{\mathrm{i}, \mathrm{c}}=\frac{P C M(\text { crisis })_{\mathrm{i}, \mathrm{c}}}{P C M(\text { pre }- \text { crisis })_{\mathrm{i}, \mathrm{c}}}-1$ for the price-cost margins and DESTREL $L_{\mathrm{i}, \mathrm{c}}=\frac{E S T(\text { crisis })_{\mathrm{i}, \mathrm{c}}}{E S T(\text { pre }- \text { crisis })_{\mathrm{i}, \mathrm{c}}}-1$ for the EST. The dummies control for industry-fixed effects. On the country level, we use either dummies or country-level variables. Note that country dummies control, among others, for the severity of the crisis and the consequent impact on average demand. As a robustness check, we include country-level variables to control for a misspecification due to possible omitted institutional differences which impact the dependent variables and are correlated with the interaction terms in Equation (1). Pre-crisis level $Y_{\mathrm{i}, \mathrm{c}}$ is either $P C M(\text { pre-crisis })_{\mathrm{i}, \mathrm{c}}$ or $E S T(\text { pre-crisis })_{\mathrm{i}, \mathrm{c}}$ and controls for country-industry differences in the level of PCM (EST) before the crisis. Note that using pre-crisis values helps in avoiding endogeneity issues. The interaction term consists of the external dependence measure of young firms, taken from RZ, and a pre-crisis institution index. This is the average of the institution index of interest in the pre-crisis period, being law and order, accountability, corruption or a composite of the three. Institutions are better for higher values of the indices. We also use the pre-crisis values of the indices to avoid endogeneity problems.

According to Hypothesis 1, we expect the coefficient of the interaction term, $\beta_{2}$, to be negative and significant only when we use a corruption index in the interaction term. This means that for more dependent industries in less corrupt countries, the drop of its PCM during a crisis is significantly deeper. This implies that the depressing effect of weakening demand was not compensated for by the uplifting effect of a significant drop in output and competition, causing a larger slide of the PCM. Hence we can interpret this 
as evidence that young firms in externally dependent sectors have better access to finance during a crisis in less corrupt countries.

According to Hypothesis 2, we expect the sign of the interaction term, $\beta_{2}$, to be positive and significant only when we use a corruption index in the interaction term. This suggests that for more dependent industries in less corrupt countries, more (young) firms survive the crisis because of better access to finance.

\section{Data}

This section describes the construction and sources of the data which we used in the analyses. An overview of the variables we used, their definitions, and their sources can be found in Table I.

The pair wise correlations between the country-level variables can be found in Panel A of Table II. Notice that the institutional indices (corruption, law and order, and accountability) are highly positively correlated. Domestic credit to GDP is also significantly positively correlated to most institutional indices, which is not surprising since this relationship is widely recognized in the finance and growth literature. In addition, GDP per capita is also highly correlated with the institutional indices and credit measures. Again, this finding corroborates with the institutions and growth literature and the financial development and growth literature. Furthermore, as expected, all corruption indices are highly positively correlated. Panel B provides correlations between the industry-level variables DPCMREL, DPCM, DESTREL, and DEST. As expected, there is a significant negative correlation between the absolute difference in the number of 
establishments (DEST) and the absolute difference of PCMs (DPCM), implying that higher PCMs are associated with fewer establishments.

Summary statistics for the datasets used in the regressions are in Table III. They can be found in Panel A and Panel B, respectively.

Note that the price-cost margin increases and the number of establishments decreases on average during a crisis.

We collected industry-level data over the period 1963-2002 from the ISIC threedigit level Industrial Statistics (IndStat) database compiled by the United Nations Industrial Development Organization (UNIDO) as it is dissipated via the World Bank's Statistical Information Management and Analysis system (SIMA). The database covers, among others, information on industry-level total value added, total value of output and total cost of wages and salaries, and the EST for 28 industries in 175 countries, although there are many missing observations ${ }^{2}$. We construct the industry-level PCM for each year for which data are available, by calculating

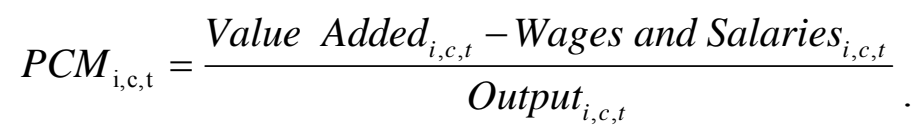

Note that although the establishments reported in the UNIDO database do not coincide with the legal boundaries of a firm, it can be interpreted as the number of competitors in the industry since it is defined as a "unit which engages, under a single ownership or control, in one, or predominantly in one, kind of activity at a single location”.

To identify system banking crisis periods, we used Caprio and Klingebiel (2003). This database describes 113 banking crises in 93 countries since the 1970s. Like Laeven, 
Klingebiel, and Krozner (2005), we restrict our analysis to the first systemic banking crisis in a country to avoid identification problems in case of multiple crises.

We took the industry-level external dependence measures for mature, young, and all firms directly from RZ. Tabel IV lists the data. External financial dependence of a firm is measured as the fraction of capital expenditures not financed with internal cash flows of US firms using COMPUSTAT. RZ take the median external financial dependence of all firms in the industry to reflect the extent to which the whole industry is dependent on external finance. RZ do not report values for Industrial Chemicals, ISIC code 351, so we draw this information from Laeven, Klingebiel, and Krozner (2005). Note that younger firms are often significantly more reliant on external finance.

We collected institutional indices for the period 1984-2004 of Accountability, Corruption, and Law and Order from the International Country Risk Guide (ICRG), an independent source, widely used by both academia and business (see for example, La Porta, 1998). All indices are on a scale from 0 to 6 , where a higher value means a better institution. We also constructed an institutional index as a composite of the individual accountability, corruption, and law and order indices, to obtain a robust estimate of the quality of institutions. Accountability is concerned with "how responsive the government is to its people." The Corruption index measures the extent to which "excessive patronage, nepotism, job reservations, 'favor-for-favors', secret party funding and suspiciously close ties between politics and business" are found in a country. Importantly, it also takes corruption practices regarding loans into account. The Law and Order index assesses "the strength and impartiality of the legal system and [...] popular observance of the law." For all indices, we calculated simple yearly averages, since ICRG reports monthly data. 
To construct the dataset for DPCMREL, we started with the UNIDO database and cleaned the data by excluding observations where value added exceeded the value of output (7,785 observations) and wages and salaries exceeded value added $(4,776$ observations). Because of missing variables, we are able to construct DPCMREL for 915 observations. ICRG coverage of institutional variables starts in 1984, therefore the set decreases to 340 observations. Because we have no external dependence measure for Industrial Chemicals and Tobacco, we lose another 24 observations. Hence, we end up with a dataset containing 316 observations, which includes Algeria, Brazil, Bulgaria, Finland, Hungary, Indonesia, Japan, Korea, Madagascar, Panama, Poland, Senegal, Sweden, Venezuela, Zambia, and Zimbabwe. Coverage is good (over 20 industries per country on average), however Algeria has 1 observation.

To construct the dataset for DESTREL, we started with the UNIDO database and cleaned the data as already described. Because of missing variables, we are able to construct DESTREL for 583 observations. ICRG coverage of institutional variables starts in 1984, therefore the dataset shrinks further to 324 observations. Because we have no external dependence measure for Industrial Chemicals and Tobacco, we lose another 23 observations. Like Laeven, Klingebiel, and Krozner (2002), we drop observations for industries which have increased over $100 \%$ during the crisis-period, since this is most probably due to increased coverage or reclassification of firms. Hence, we end up with a dataset containing 260 observations, which includes Brazil, Bulgaria, Finland, Hungary, Indonesia, Japan, Korea, Panama, Poland, Senegal, Sweden, Venezuela, Zambia, and Zimbabwe. Coverage of industries is good (on average more than 20 industries), except for Bulgaria, Hungary, and Senegal which have fewer than 3 observations. 
The constructed datasets only contain countries that experienced crises in the late 1980s and 1990s. The average number of observations per country is around 20 out of 28 industries. Tables V and VI provide an overview of the averages of variables used for the regressions with the relative changes in PCM and EST, respectively.

In the robustness checks, we also use GDP per capita, inflation, and domestic credit to GDP as country-level controls. All are drawn from the World Development Indicators of the World Bank. We collected three other corruption indices. We use the Corruption Perceptions Index from Transparency International (henceforth TI). Since this index was first constructed in 1995 and has limited coverage, we use an average of the index for the period 1996-1997. We also collected a second corruption index by Beck et al. (2000, henceforth when referring to the indicator: Beck), which is an average for the period 1982-1995. Finally, we use the corruption index of Kaufman and Kraay (1999, henceforth KKZ).

\section{Main Results}

This section deals with the main results of the paper and some initial robustness checks. All standard errors for OLS regressions reported in the paper are robust to heteroskedasticity using the Huber-White estimator of variance. In the main results, we focus on access to finance for young firms as being the specific channel through which DPCMREL and DESTREL are affected. For DPCMREL, the results are reported in Table VII, Columns (1)-(4), where external dependence is interacted with several institutional indices. They reflect the basic result for Hypothesis 1 of the paper. 
We can see that the interaction term for corruption is significant on the $1 \%$ level and positive, suggesting that indeed PCMs are higher during crises in industries which are dependent on external finance in countries with higher corruption, also after controlling for financial development, presented in Columns (5)-(8). Corruption seems to be the most important factor, since the interaction term of external dependence and other institutional indices are not significant. This provides a robustness check on the channel of corruption. Only in Column (8) is the interaction of the average institutional index is significant, which is probably driven by the Corruption index.

We can use the regression coefficient estimates of Table VII to infer how much deeper the relative PCM would fall of an industry at the $75^{\text {th }}$ percentile of financial dependence compared to an industry at the $25^{\text {th }}$ percentile level, when the industries are located in a country at the $75^{\text {th }}$ percentile of corruption, rather than in a country at the $25^{\text {th }}$ percentile. The industry at the $75^{\text {th }}$ percentile, Petroleum Refineries, has an external dependence measure of 0.85 . The industry at the $25^{\text {th }}$ percentile, Wood Products, has a dependence measure of 0.34 . The country at the $75^{\text {th }}$ percentile of corruption has a value of 4.1 for the corruption index and the countries at the $25^{\text {th }}$ percentile have a value of 3 . The estimated coefficient for the interaction term in Regression 5 of Table VII equals 0.052 and we can set the industry's initial share of manufacturing at its overall mean. The regression coefficient estimates therefore predicts the difference in relative PCM change between the $75^{\text {th }}$ and $25^{\text {th }}$ percentile of external dependence is 2.9 percent lower in a country with a corruption index of 3 compared to one with an index of 4.1. For comparison, the average relative PCM change during crisis is 5 percent. Therefore, a differential change of -2.9 percent due to an improvement in the corruption index from 3 to 4.1 represents a large decrease. 
For DESTREL, the main results can be found in Table VIII, Columns (1)-(4), where external dependence is interacted with several institutional indices. They reflect the basic result for Hypothesis 2 of the paper.

Only the interaction term with the Corruption index is significant (on the 5\% level), which identifies corruption as the most important channel. Using the regression coefficient of the interaction term with corruption (0.037) of Regression 5, a relative EST change between the $75^{\text {th }}$ and $25^{\text {th }}$ percentile of external dependence is 2.1 percent higher in a country with a corruption index of 3 compared to one with an index of 4.1. For comparison, the average relative EST change during crisis is -5.2 percent. ${ }^{3}$ Therefore, a differential change of 2.1 percent due to an improvement in the corruption index from 3 to 4.1 represents a large increase.

\section{Robustness Checks}

This section contains several robustness checks of the main result. Tables VII and VIII showed that the results are robust to controlling for financial development.

First, the data seem to support that indeed young firms are most adversely affected. We conclude this because the results in Tables VIII and IX can not be replicated when using the external dependence measure of $\mathrm{RZ}$ for all firms. In that case none of the interaction terms are significant. These results are presented in Table IX, Columns (1) and (3).

Furthermore, we ran the regressions using the difference in external dependence between young and mature firms instead of young firms only (Columns (2) and (4)). The intuition is that we expect even more malpractices in industries where the external dependence gap between young and mature firms is large. However, only for DESTREL 
is the interaction term significant (at the 10\% level) and marginally so for DPCMREL (at the $10.7 \%$ level) $)^{4}$. The results in Columns (2) and (4) need not be surprising. If indeed connections are important, even mature firms which are also highly dependent on external finance would be able to get access to finance themselves, while lobbying to exclude others.

Second, the results in Tables VII and VIII are robust to omitting outliers. We checked this by running the basic regressions after cutting of the $1 \%$ and $5 \%$ tails of the distribution of the dependent variable, and using robust estimation techniques like Iteratively Weighted Least Squares regressions and Absolute Least Value regressions ${ }^{5}$.

Third, the results are robust to using an alternative measure of financial development: total domestic credit to GDP. The results are reported in Table X.

Fourth, to check the results we used three different corruption measures. We took an average of the Corruption Perceptions Index in the period 1996-1997 from Transparency International. In addition, we adopted the corruption index from Beck et al. (2000), which is an average over the period 1982-1995. Lastly, we used the KKZ index of Kaufmann, Kraay, and Zoido-Lobaton (1999). All indices are ranged on a scale from 1-10, where a higher score indicates less corruption. The number of observations differ however greatly over the specifications, because coverage of corruption indices is in general poor for the 1980s and early 1990s. Tabel XI presents the results.

The interaction terms with the Transparency International index and the KKZ index confirm the results. However, the Beck et al. (2000) indicator does not produce significant results when explaining DESTREL, despite the fact that all corruption measures are highly positively correlated. 
Fifth, there might be a misspecification when the interaction term is correlated with omitted country variables which affect the dependent variable. Therefore we dropped the country-level variables and used other country controls. We employed GDP per capita, inflation, total domestic credit over GDP, domestic credit via banks over GDP, and the corruption index. As usual, the controls are pre-crisis averages. Table XII reports the results.

The results are robust to different specifications, and get stronger when more variables are added to the model. Although the sample size shrinks when more variables are added, it is noteworthy to state that the coefficients are close to the coefficients in the main results.

Sixth, as a further robustness check, we transformed the corruption variable in the interaction term into a dummy which takes a value of one if the corruption index is higher than the median, and zero otherwise. This new interaction term is positive and highly significant for DESTREL (Table XIII, Column (6)). However, it is no longer significant when explaining DPCMREL (Table XIII, Column (3)). To investigate this, we ran the regressions for the sub samples which have higher and lower values of corruption. To reduce the effect of outliers, the $1 \%$ tails of the dependent variable are dropped. ( 7 observations) Table XIII reports the results.

Column (1) shows that for the most corrupt countries, the interaction term is again significant. However, it is not for countries with low levels of corruption (Column (2)). To check for non-linearity, we added a second interaction term with a squared corruption index (Column (3)). Both interaction terms are also highly significant for the complete sample, using Iteratively Weighted Least Squares to reduce the impact of outliers. The coefficients indicate that when the corruption index takes on a value of around 4.6, the 
marginal effect of the interaction terms is almost zero. Hence, these results indicate that impact of the interaction term is largest for the most corrupt countries. To check this, we ran three quantile regressions (for $0.1,0.5$, and 0.9$)^{7}$. We expect that the effect is highest for the highest quantile of the DPCMREL distribution, since the hypothesis indicates those countries should be most corrupt. Indeed, Columns (4)-(6) show that the value of the interaction term doubles for the 0.9 quantile relative to the other quantiles. Although we don't provide a theory for the decreasing coefficient for the pre-crisis PCM, this perhaps can be interpreted that collusive behavior becomes unsustainable in the event of an exogenous shock.

Seventh, the results are robust to including time dummies to correct for the general external environment of the crisis (not reported).

Eighth, the country dummies implicitly control for the severity of the crisis and the accompanying effect of a currency devaluation on the terms of trade. However in addition to Table XII, we also explicitly want to control for changes in the terms of trade. Table XIV produces the results. The interaction term with corruption remains significant for both the change in PCM as the number of establishments.

Finally, we performed a more general check whether access to finance is opportunistically curtailed for young firms. We explored the effect of the informativeness of industries on the dependent variables. Informativeness can be seen as a proxy for financial development. Since, unlike RZ's external dependence, this index is not based on accounting measures, it is more exogenous to the model. In doing so, we ran a regression similar to Equation (1): 


$$
\begin{aligned}
& Y_{\mathrm{i}, \mathrm{c}}=\text { Intercept }+ \text { Industry dummies }{ }_{i}+\text { Country dummies }_{c} \\
& +\beta_{1} \cdot \text { Pre - } \text { crisis level }_{i, c} \\
& +\beta_{2} \cdot \text { Informativeness }_{\mathrm{i}} \cdot \text { Pre - crisis corruption }{ }_{\mathrm{c}} \\
& +\varepsilon_{i, c} \text {, }
\end{aligned}
$$

where Informativeness $s_{i}$ is substituted for external financial dependence. This index measures how much information is conveyed by movements in industry stock market prices in the United States in the period $1980-1982^{8}$. It is based on the idea of Durnev, Morck and Yeung (2004) that higher stock price comovement reveals less industryspecific information. Hence, an industry can be considered more opaque for lower index values. Intuitively, PCM and EST are more susceptible to malpractices in opaque industries, which are more easily manipulated due to a lack of outside scrutiny. Therefore, we expect the interaction term to be significant and positive when $Y_{\mathrm{i}, \mathrm{c}}$ is DPCMREL, suggesting that in more opaque industries in countries which are corrupt, the PMC is relatively high during crises. We expect the opposite to be true for DESTREL. The results are reported in columns (1)-(4) of Table XV. Explaining DPCMREL in Column (1) and (2), we see that the interaction term is highly significant at the $1 \%$ level and has the expected sign, also after controlling for financial development of the banking system. The effect is as expected, but less strong when trying to explain DESTREL in Column (1) and (2), and only significant at the $10 \%$ level after controlling for financial development. Interestingly, the informativeness measure and the external dependence of young firms is negative and significant $(\rho=-0.67$ and $p=0.00)$ and less so for dependence of all firms $(\rho=-0.36$ and $p=0.01)$. 


\section{Conclusion}

The main question this paper addresses is whether incumbents use their connections to curtail access to finance during a systemic banking crisis to weaken or even eliminate their younger competitors. The data provide support for this view. Our main finding is that industries in which young firms are highly dependent on external finance have (1) relatively high price-cost margins (PCMs) and (2) relatively fewer establishments during systemic banking crises in countries with higher corruption indices. These results withstand an array of robustness checks, including different controls, and robust estimation techniques. Combined, we can regard these results as indirect evidence that powerful interests - strong, well-connected firms and/or their banks - are able to restrict access to finance during a crisis for younger firms, forcing them to significantly reduce output or even to default. Furthermore, we find that the described effect on the relative PCM change is disproportionately higher in countries with higher corruption. Interestingly, we also find that the PCM is higher during crises in informationally more opaque industries -a measure of industry stock price comovement- in more corrupt countries experience relatively higher PCMs, suggesting that a "smoke screen" leads to malpractices in general, where the financial channel is just one of many ways to weaken competitors.

The findings may have policy implications. They indicate that the effect of corruption on access to finance can play an important role in the impact of banking crises on the post-crisis structure of the real sector. 


\section{REFERENCES}

Acemoglu, Daron, James Robinson, and Simon Johnson, 2001, The Colonial Origins of Comparative Development: An Empirical Investigation, American Economic Review 91, 1369-1401.

Beck, Thorsten, Luc Laeven, Asli Demirgüç-Kunt, and Vojislav Maksimovic, 2003, The Determinants of Financing Obstacles, Journal of International Money and Finance, forthcoming.

Thorsten, Ross Levine, and Norman Loayza, 2000, Finance and the Sources of Growth, Journal of Financial Economics 58, 261-300.

Beck, Thorsten, Asli Demirgüç-Kunt, and Ross Levine, 2003, Law, Endowments, and Finance, Journal of Financial Economics 70, 137-181.

Beck, Thorsten, Asli Demirguc-Kunt and Ross Levine, 2004, "Law and Firms' Access to Finance, mimeo World Bank, forthcoming in American Law and Economics Review.

Braun, Mattias and Claudio Raddatz, 2005, Trade Liberalization and the Politics of Financial Development, FRB of Boston Working Paper 04-3; World Bank Policy Research Working Paper 3517.

Caprio, Gerard, and Daniela Klingebiel, 2003, Episodes of Systemic and Borderline Financial Crises, World Bank Database.

Ceterolli, Nicola, and Michele Gambera, 2001, Banking Market Structure, Financial Dependence And Growth: International Evidence From Industry Data, Journal of Finance 56, 617-648. 
Claessens, Stijn and Luc Laeven, 2003, Financial Development, Property Rights, and Growth, Journal of Finance 58, 2401-2436.

Claessens, Stijn, Simeon Djankov, and Giovanni Ferri, 1999, Corporate Distress in East Asia: Assessing the Impact of Interest and Exchange Rates Shocks, Emerging Markets Quarterly 3.

Claessens, Stijn, Simeon Djankov and Lixin Colin Xu, 2000, Corporate Performance in the East Asian Financial Crisis, World Bank Research Observer 15, 23-46.

Claessens, Stijn, Simeon Djankov and Leora Klapper, 2003, Resolution of Corporate Distress in East Asia, Journal of Empirical Finance 10, 199-216.

Demirguc-Kunt, Asli, and Enrica Detragiache, 1998, Financial Liberalization and Financial Fragility, mimeo World Bank.

Demirgüç-Kunt, Asli, and Vojislav Maksimovic, 1998, Law, Finance, and Firm Growth, Journal of Finance 53, 2107-2137.

Demirgüç-Kunt, Asli, and Vojislav Maksimovic, 1999, Institutions, Financial Markets, And Firm Debt Maturity, Journal of Financial Economics 54, 295-336.

Djankov, Simeon, Rafael La Porta, Florencio Lopez-de-Silanes, and Andrei Shleifer, 2002, The Regulation of Entry, Quarterly Journal of Economics 117, 1-37.

Durnev, Art, Randall Morck, and Bernard Yeung, 2004, Value-Enhancing Capital Budgeting and Firm-Specific Stock Return Variation, Journal of Finance 41, 797835.

Facco, Mara, 2004, Politically Connected Firms, mimeo Vanderbilt University.

Feijen, Erik and Enrico Perotti, 2005, The Political Economy of Financial Fragility, mimeo University of Amsterdam. 
Fisman, Raymond, 2001, Estimating the Value of Political Connections, American Economic Review 91, 1095-1102.

Fisman, Raymond, and Virginia Sarria-Allende, 2004, Regulation of Entry and the Distortion of Industrial Organization, mimeo Columbia Business School.

Halac, Marina and Sergio Schmuckler, 2003, Distributional Effects of Crises: The Role of Financial Transfers, mimeo World Bank.

Haber, Stephen, 2004, Political Institutions, Bank Entry and Economic Growth: Evidence from the US and Mexico, mimeo Stanford University.

He, Kathy, Randall Morck, and Bernard Yeung, 2000, Corporate Stability, mimeo, New York University.

Huang, Rocco, 2005, Tolerance for Uncertainty and Ambiguity and the Growth of Informationally Opaque Industries, Mimeo University of Amsterdam.

Jayaratne, Jith and Philip Strahan, 1996, The Finance-Growth Nexus: Evidence from Bank Branch Deregulation, Quarterly Journal of Economics 111, 639-670.

Johnson, Simon, Peter Boone, Alasdair Breach, and Eric Friedman, 2000, Corporate Governance in the Asian Financial Crisis, Journal of Financial Economics 58, 141186.

Johnson, Simon and Todd Mitton, 2002, Cronyism and Capital Controls: Evidence from Malaysia, Journal of Financial Economics 67, 351-382.

Johnson, Simon, John McMillan, and Christopher Woodruff, 2002, Property rights and finance, American Economic Review 92, 1335-1356.

Kaufmann, Daniel, Kraay, Aart, and Zoido-Lobaton, Pablo, 1999, Governance Matters, World Bank Policy Research Working Paper 2196. 
Keefer, Philip, (undated), Elections, Special Interests and the Fiscal Costs of Financial Crisis, mimeo World Bank.

King, Robert G., and Ross Levine, 1993, Finance and Growth: Schumpeter Might Be Right, Quarterly Journal of Economics 108, 717-737.

Klapper, Leora, Luc Laeven, and Raghuram Rajan, 2004, Business Environment and Firm Entry: Evidence from International Data, mimeo World Bank.

Khwaja, Asim Ijaz, and Atif Mian, 2004, Do Lenders Favor Politically Connected Firms? Rent Provision in an Emerging Financial Market, mimeo Harvard University.

Laeven, Luc, 2001, Insider Lending and Bank Ownership, The Case of Russia, Journal of Comparative Economics 29, 207-229.

Laeven, Luc, Daniela Klingebiel, and Randall Kroszner, 2005, Financial Crises, Financial Dependence, and Industry Growth, World Bank Policy Research Paper 2855.

La Porta, Rafael, Florencio Lopez-de-Silanes, Andrei Shleifer, and Robert W. Vishny, 1997, Legal determinants of External Finance, Journal of Finance 52, 1131-1150.

La Porta, Rafael, Florencio Lopez-de-Silanes, Andrei Shleifer, and Robert W. Vishny, 1998, Law and finance, Journal of Political Economy 106, 1113-1155.

La Porta, Rafael, Florencio Lopez-de-Silanes, and Guillermo Zaparripa, 2002, Related Lending, mimeo Yale.

Levine, Ross, 2004, Financial and growth: Theory and Evidence, NBER Working Paper 10766.

Levine, Ross, and Sara Zervos, 1998, Stock Markets, Banks, and Economic Growth, American Economic Review 88, 537-558.

Perotti, Enrico, and Paolo Volpin, 2004, Lobbying on Entry, CEPR Discussion Paper 4519. 
Rajan, Raghuram, and Luigi Zingales, 1998, Financial Dependence and Growth, American Economic Review 88, 559-586.

Rajan, Raghuram, and Zingales, Luigi, 2003, The Great Reversals: The Politics of Financial Development in the 20th Century, Journal of Financial Economics 69, 550.

Stiglitz, Joseph E., and Andrew Weiss, 1981, Credit Rationing in Markets with Imperfect Information, American Economic Review 71, 393-410. 


\section{Footnotes}

\footnotetext{
${ }^{1}$ For an overview of the causes and effects of the East-Asian crisis on corporate sectors, see Claessens et al. (2000).

${ }^{2}$ Some countries can have changed names, like, for example, Yemen, and have multiple entries in the database.

${ }^{3}-5.2 \%$ is the average for the universe for which DESTREL could be calculated. The average for the sample used for the regressions can be found in Table III.

${ }^{4}$ However, when the $1 \%$ tails of the DPCMREL distribution are dropped, the interaction terms become significant for both new measures of external dependence.

${ }^{5}$ Iteratively Least Squares takes outliers into account by assigning a weight to each observation with higher weights given to "better behaved" observations. Least Absolute Values is in fact a median regression where the absolute deviations from the median are used to calculate the coefficients.

${ }^{6}$ Transparency International started constructing the index in 1995, but not for all countries. Therefore we use 1996 and 1997.

${ }^{7}$ Quantile regressions use the whole sample to estimate the coefficients for the conditional expected value of the desired quantile. The 0.5 -quantile is a special case, where the conditional median value is estimated.

${ }^{8}$ We took the measure from Huang (2005). Huang reports that this index does not change much over time. Huang follows Durnev, Morck and Yeung (2004) and uses "relative firm-specific stock return variations" to measure stock price informativeness at the industry level.
} 


\section{Table I}

\section{Definition and Source of Variables}

This table describes all the variables we use. The first column gives the name of the variable. The second column describes the variable and provides the source from which it was collected.

\begin{tabular}{|c|c|}
\hline Variable & Description \\
\hline DPCMREL & $\begin{array}{l}\text { The relative change of the average industry level Price Cost Margin in the systemic banking crisis period } \\
\text { relative to the pre-crisis period (definition in text). The Price Cost Margin (PCM) itself is calculated by value } \\
\text { added minus wages and salaries over value of output. Where wages and salaries and value added are not } \\
\text { allowed to exceed value added and output, respectively. Source: UNIDO IndStat ISIC level } 3 \text { 1963-2003; own } \\
\text { calculations. }\end{array}$ \\
\hline DESTREL & $\begin{array}{l}\text { The relative change of the average number of establishments (EST) in the systemic banking crisis period } \\
\text { relative to the pre-crisis period (definition in text). Source: UNIDO IndStat ISIC level } 3 \text { 1963-2003; own } \\
\text { calculations. }\end{array}$ \\
\hline $\begin{array}{l}\text { Pre-crisis PCM } \\
(\text { EST) }\end{array}$ & $\begin{array}{l}\text { The average industry level Price Cost Margin (EST) in the pre-crisis period. Source: UNIDO IndStat ISIC } \\
\text { level } 3 \text { 1963-2003; own calculations. }\end{array}$ \\
\hline Terms of Trade & $\begin{array}{l}\text { The relative change of in the terms of trade during the banking crisis period relative to the pre-crisis period. } \\
\text { Source: own calculations, World Development Indicators }\end{array}$ \\
\hline $\begin{array}{l}\text { External } \\
\text { dependence }\end{array}$ & $\begin{array}{l}\text { Median external financial dependence of young U.S. firms by ISIC sector averaged over the period 1980- } \\
\text { 1989. Source: Rajan and Zingales (1998). }\end{array}$ \\
\hline Accountability & $\begin{array}{l}\text { The average of the Accountability index in the pre-crisis period. The index is on a scale from } 0 \text { to } 6 \text {. A higher } \\
\text { index means higher accountability. The index is concerned with "how responsive the government is to its } \\
\text { people." We use the average value of the index in the pre-crisis period. Source: International Country Risk } \\
\text { Guide, January } 2005 \text {. }\end{array}$ \\
\hline Corruption & $\begin{array}{l}\text { The average of the Corruption index in the pre-crisis period. The index is on a scale from } 0 \text { to } 6 \text {. A higher } \\
\text { index means lower corruption. The index is concerned with "excessive patronage, nepotism, job reservations, } \\
\text { 'favor-for-favors', secret party funding and suspiciously close ties between politics and business." Source: } \\
\text { International Country Risk Guide. }\end{array}$ \\
\hline Law and Order & $\begin{array}{l}\text { The average of the Law and Order index in the pre-crisis period. The index is on a scale from } 0 \text { to } 6 . \text { A higher } \\
\text { index means better law and order. The index is concerned with "[assessing] the strength and impartiality of } \\
\text { the legal system and [...] popular observance of the law." Source: International Country Risk Guide. }\end{array}$ \\
\hline $\begin{array}{l}\text { Institutional } \\
\text { index }\end{array}$ & $\begin{array}{l}\text { The simple average of Law And Order, Corruption, and Accountability. Source: International Country Risk } \\
\text { Guide; own calculations. }\end{array}$ \\
\hline $\begin{array}{l}\text { Corruption } \\
\text { (Beck) }\end{array}$ & $\begin{array}{l}\text { Measure of corruption, with the scale readjusted to } 0 \text { (high level of corruption) to } 10 \text { (low level). Data are } \\
\text { averaged over 1982-1995. Higher values correspond to better governance. Source: Beck et al. (2000). }\end{array}$ \\
\hline Corruption (TI) & $\begin{array}{l}\text { The average Corruption Perceptions Index of a country over } 1996 \text { and } 1997 \text {. The CPI focuses on corruption in } \\
\text { the public sector and defines corruption as the abuse of public office for private gain. The index is on a scale } \\
\text { from } 1 \text { to } 10 \text {. Source: Transparency International. }\end{array}$ \\
\hline KKZ & $\begin{array}{l}\text { A composite of six governance indicators (1998 data): voice and accountability, political stability, government } \\
\text { effectiveness, regulatory quality, rule of law, and corruption. Higher values correspond to better governance. } \\
\text { Source: Kaufman, Kraay, and Zoido-Lobaton (1999). }\end{array}$ \\
\hline $\begin{array}{l}\text { Total Credit to } \\
\text { GDP }\end{array}$ & Average total domestic (\% of GDP) in the pre-crisis period. Source: World Development Indicators. \\
\hline $\begin{array}{l}\text { Credit via banks } \\
\text { to GDP }\end{array}$ & $\begin{array}{l}\text { Average domestic credit provided by banking sector (\% of GDP) in the pre-crisis period. Source: World } \\
\text { Development Indicators. }\end{array}$ \\
\hline Inflation & Average inflation in the pre-crisis period. Source: World Development Indicators. \\
\hline GDP per capita & Average GDP per capita in 1995 US \$ in the pre-crisis period. Source: World Development Indicators. \\
\hline
\end{tabular}




\section{Table II}

\section{Simple Correlations}

This table describes pair wise correlations. Panel A contains country-level variables. Panel B contains country/industrylevel variables. $*, * *$ indicate significance at $5 \%$, and $1 \%$ level, respectively

Panel A:

\begin{tabular}{|c|c|c|c|c|c|c|c|c|c|c|}
\hline & $\mathrm{COR}$ & $\mathrm{ACC}$ & LAW & CRED & $\begin{array}{l}\text { DOM- } \\
\text { PRIV }\end{array}$ & GDPC & INFL & COR(TI) & $\begin{array}{l}\text { COR } \\
\text { (KKZ) }\end{array}$ & $\mathrm{COR}(\mathrm{B})$ \\
\hline COR & 1.00 & & & & & & & & & \\
\hline $\mathrm{ACC}$ & $0.73 * *$ & 1.00 & & & & & & & & \\
\hline LAW & $0.77 * *$ & $0.55 * *$ & 1.00 & & & & & & & \\
\hline \multirow[t]{2}{*}{ CRED } & 0.15 & 0.26 & 0.07 & 1.00 & & & & & & \\
\hline & 0.48 & 0.20 & 0.73 & & & & & & & \\
\hline DOMPRIV & $0.47^{*}$ & $0.51^{* *}$ & $0.58 * *$ & $0.68^{* *}$ & 1.00 & & & & & \\
\hline GDP & $0.67 * *$ & $0.62 * *$ & $0.72 * *$ & $0.41^{* *}$ & $0.68 * *$ & 1.00 & & & & \\
\hline INFLATION & -0.23 & -0.16 & $-0.47 *$ & -0.08 & -0.19 & -0.17 & 1.00 & & & \\
\hline COR (TI) & $0.91 * *$ & $0.77 * *$ & $0.85^{* *}$ & $0.50^{* *}$ & $0.50 * *$ & $0.85 * *$ & -0.26 & 1.00 & & \\
\hline COR (KKZ) & $0.89 * *$ & $0.72 * *$ & $0.81^{* *}$ & $0.31 *$ & $0.47 * *$ & $0.76^{* *}$ & -0.20 & $0.91 * *$ & 1.00 & \\
\hline COR (B) & $0.97 * *$ & $0.80 * *$ & $0.90 * *$ & 0.26 & $0.63 * *$ & $0.80 * *$ & -0.22 & $0.88 * *$ & $0.80 * *$ & 1.00 \\
\hline
\end{tabular}

Panel B:

\begin{tabular}{lcccc}
\hline & DPCMREL & DPCM & DESTREL & DEST \\
\hline DPCMREL & 1.00 & & & \\
DPCM & $0.76^{* *}$ & 1.00 & & \\
DESTREL & -0.07 & $-0.13^{*}$ & 1.00 & \\
DEST & -0.06 & $-0.15^{* *}$ & $0.19^{* *}$ & 1.00 \\
\hline
\end{tabular}




\section{Table III}

\section{Descriptive Statistics of Basic Datasets Used}

This table reports summary statistics. It displays the variable, the number of observations, its arithmetic mean, its standard deviation and its minimum and maximum values. Panel A pertains to the regressions with the relative change in price-cost margins (DPCMREL) during a systemic banking crisis as the dependent variable. Panel B contains statistics for the regressions using the relative change in the number of establishments (DESTREL) as the dependent variable. DPCM and DEST denote the absolute changes during a crisis for the Price-Cost Margin (PCM) and the number of establishments (EST), respectively.

\section{Panel A:}

\begin{tabular}{|c|c|c|c|c|c|}
\hline Variable & Observations & Mean & Std. Dev. & Min & Max \\
\hline DPCMREL & 340 & 0.05 & 0.65 & -0.97 & 8.02 \\
\hline DPCM & 340 & -0.01 & 0.10 & -0.36 & 0.55 \\
\hline Pre crisis PCM & 340 & 0.28 & 0.11 & 0.02 & 0.75 \\
\hline Corruption & 340 & 3.75 & 1.35 & 1.60 & 6.00 \\
\hline Accountability & 340 & 3.90 & 1.53 & 1.86 & 6.00 \\
\hline Law and Order & 340 & 3.77 & 1.49 & 1.70 & 6.00 \\
\hline Credit via banks to GDP (\%) & 340 & 72.92 & 52.50 & 5.36 & 223.71 \\
\hline Credit to GDP (\%) & 340 & 51.70 & 37.89 & 4.45 & 153.53 \\
\hline GDP per capita & 313 & 9310.78 & 11104.96 & 300.15 & 32053.45 \\
\hline Corruption (TI) & 340 & 29.47 & 57.56 & 1.38 & 338.45 \\
\hline Corruption (KKZ) & 242 & 0.52 & 0.79 & -0.76 & 1.62 \\
\hline Corruption (Beck) & 203 & 5.75 & 2.55 & 2.64 & 9.26 \\
\hline \multicolumn{6}{|l|}{ Panel B: } \\
\hline Variable & Observations & Mean & Std. Dev. & Min & Max \\
\hline DESTREL & 260 & 0.02 & 0.34 & -1.00 & 1.00 \\
\hline DEST & 260 & -239.93 & 2129.72 & -27143.00 & 4226.67 \\
\hline Pre crisis EST & 260 & 2469.97 & 7416.45 & 1.00 & 50689.60 \\
\hline Corruption & 260 & 3.73 & 1.49 & 1.60 & 6.00 \\
\hline Accountability & 260 & 3.91 & 1.63 & 1.86 & 6.00 \\
\hline Law and Order & 260 & 3.66 & 1.56 & 1.70 & 6.00 \\
\hline Credit via banks to GDP (\%) & 260 & 72.41 & 55.99 & 5.36 & 223.71 \\
\hline Credit to GDP (\%) & 260 & 54.35 & 40.76 & 4.45 & 153.53 \\
\hline GDP per capita & 235 & 10946.60 & 11725.52 & 492.29 & 32053.45 \\
\hline Corruption (TI) & 163 & 5.89 & 2.71 & 2.64 & 9.26 \\
\hline Corruption (KKZ) & 208 & 0.47 & 0.81 & -0.76 & 1.62 \\
\hline Corruption (Beck) & 189 & 6.82 & 2.39 & 3.51 & 10.00 \\
\hline
\end{tabular}




\section{Table IV}

\section{External Financial Dependence of US Firms in the Period 1980-1989}

This table reports the median level of external financing needs during 1980-1989 on the three-digit ISIC level. The higher the index the more dependent is the industry on external finance. External dependence is measured as the fraction of capital expenditures not financed with internal cash flows. The data is directly from Rajan and Zingales (1998). The data for Industrial chemicals, ISIC code 351, is from Laeven, Klingebiel, and Krozner (2002).

\begin{tabular}{|c|c|c|c|c|}
\hline \multirow[b]{2}{*}{ ISIC code } & \multirow[b]{2}{*}{ Industrial sector } & \multirow[b]{2}{*}{ All } & \multicolumn{2}{|c|}{ Age of company } \\
\hline & & & Mature & Young \\
\hline 313 & Beverages & 0.08 & -0.15 & 0.63 \\
\hline 311 & Food products & 0.14 & -0.05 & 0.66 \\
\hline 324 & Footwear & -0.08 & -0.57 & 0.65 \\
\hline 332 & Furniture & 0.24 & 0.33 & 0.68 \\
\hline 351 & Industrial chemicals & 0.25 & - & - \\
\hline 362 & Glass & 0.53 & 0.03 & 1.52 \\
\hline 371 & Iron and steel & 0.09 & 0.09 & 0.26 \\
\hline 323 & Leather & -0.14 & -1.33 & -1.53 \\
\hline 382 & Machinery & 0.45 & 0.22 & 0.75 \\
\hline 383 & Electric machinery & 0.77 & 0.23 & 1.22 \\
\hline 381 & Metal products & 0.24 & 0.04 & 0.87 \\
\hline 372 & Non-ferrous metal & 0.01 & 0.07 & 0.46 \\
\hline 369 & Non-metal products & 0.06 & 0.15 & -0.03 \\
\hline 352 & Other chemicals & 0.22 & -0.18 & 1.35 \\
\hline 390 & Other industries & 0.47 & -0.05 & 0.8 \\
\hline 341 & Paper and products & 0.18 & 0.1 & 0.57 \\
\hline 354 & Petroleum and coal products & 0.33 & 0.16 & -0.26 \\
\hline 353 & Petroleum refineries & 0.04 & -0.02 & 0.85 \\
\hline 356 & Plastic products & 1.14 & - & 1.14 \\
\hline 361 & Pottery & -0.15 & 0.16 & -0.41 \\
\hline 342 & Printing and publishing & 0.2 & 0.14 & 0.6 \\
\hline 385 & Professional goods & 0.96 & 0.19 & 1.63 \\
\hline 355 & Rubber products & 0.23 & -0.12 & 0.5 \\
\hline 321 & Textile & 0.4 & 0.14 & 0.66 \\
\hline 314 & Tobacco & -0.45 & -0.38 & - \\
\hline 384 & Transportation equipment & 0.31 & 0.16 & 0.58 \\
\hline 322 & Apparel & 0.03 & -0.02 & 0.27 \\
\hline 331 & Wood products & 0.28 & 0.25 & 0.34 \\
\hline
\end{tabular}


Table V

\section{Country-level Averages of Variables Used in Basic Regressions with the Change in Price-Cost Margins as the Dependent Variable}

This table shows summary statistics on the national level for which we have enough data to construct differences in industry-level price-cost margins (PCMs) between the crisis and pre-crisis period. The PCM is defined as value added minus wages and salaries over value of total output. The pre-crisis period is defined as [t- $8, t-3]$ and the crisis period is defined as $[t-1, t+1]$, where $t$ is the first year of the first systemic banking crisis in a country according to Caprio and Klingebiel (2003). DPCM is the absolute difference in PCM between the crisis and the pre-crisis period. DPCMREL is the relative difference. The Corruption, Accountability, and Law and Order institutional indices are on a scale from 0 to 6 , where a higher score indicates a better institution. The Institutional index is a composite of all institutional indices. Institutional indices are drawn from ICRG. Credit via Banks is the domestic credit as a \% of GDP from the WDI. Credit to GDP, GDP per capita, and Inflation are all from the WDI. Corruption (TI) is the perceived corruption index by Transparency International. The Corruption (Beck) measure is from Beck et al. (2000). The external dependence measures are based on Rajan and Zingales (1998).

\begin{tabular}{|c|c|c|c|c|c|c|c|c|c|c|c|c|c|c|c|c|}
\hline \multirow[b]{2}{*}{ Country } & \multirow[b]{2}{*}{$\begin{array}{c}\text { Crisis } \\
\text { date }\end{array}$} & \multirow{2}{*}{$\begin{array}{c}\text { Number } \\
\text { of } \\
\text { Industries }\end{array}$} & \multirow[b]{2}{*}{ DPCM } & \multirow[b]{2}{*}{ DPCMREL } & \multicolumn{12}{|c|}{ Averages values in pre-crisis period } \\
\hline & & & & & $\mathrm{PCM}$ & Corruption & Accountability & $\begin{array}{c}\text { Law and } \\
\text { Order }\end{array}$ & $\begin{array}{c}\text { Institutional } \\
\text { index }\end{array}$ & $\begin{array}{c}\text { Corruption } \\
\text { (TI) }\end{array}$ & $\begin{array}{c}\text { Corruption } \\
(\text { KKZ) }\end{array}$ & $\begin{array}{c}\text { Corruption } \\
(\text { Beck })\end{array}$ & $\begin{array}{l}\text { Credit via } \\
\text { Banks (\%) }\end{array}$ & $\begin{array}{l}\text { Credit to } \\
\text { GDP (\%) }\end{array}$ & $\begin{array}{c}\text { GDP per } \\
\text { capita }\end{array}$ & Inflation \\
\hline Algeria & 1990 & 1 & -0.056 & -0.194 & 0.291 & 3.667 & 2.000 & 2.000 & 2.556 & - & - & - & 87.565 & 59.108 & 1796.908 & 10.323 \\
\hline Brazil & 1990 & 11 & 0.106 & 0.359 & 0.348 & 3.806 & 3.861 & 3.861 & 3.843 & 3.260 & 0.000 & 6.310 & 51.421 & 44.580 & 3952.198 & 160.165 \\
\hline Bulgaria & 1995 & 8 & -0.023 & 0.114 & 0.232 & 3.083 & 3.083 & 5.000 & 3.722 & - & - & - & 118.516 & 7.204 & 1586.882 & 338.449 \\
\hline Finland & 1991 & 28 & -0.022 & -0.034 & 0.237 & 6.000 & 6.000 & 6.000 & 6.000 & 9.265 & 1.620 & 10.000 & 58.885 & 61.513 & 23276.260 & 5.657 \\
\hline Hungary & 1991 & 27 & -0.039 & 0.074 & 0.202 & 4.000 & 4.667 & 5.000 & 4.556 & 5.020 & 0.870 & - & 99.867 & 51.375 & 4686.407 & 7.207 \\
\hline Indonesia & 1997 & 26 & 0.002 & 0.015 & 0.290 & 1.600 & 3.000 & 2.833 & 2.478 & 2.685 & -0.760 & - & 43.983 & 44.164 & 827.386 & 8.171 \\
\hline Japan & 1991 & 28 & 0.024 & 0.113 & 0.242 & 5.000 & 6.000 & 5.000 & 5.333 & 6.810 & 0.950 & 8.512 & 223.709 & 153.530 & 32053.450 & 1.384 \\
\hline Korea & 1997 & 28 & 0.038 & 0.141 & 0.312 & 4.100 & 2.550 & 2.150 & 2.933 & - & - & 5.298 & 63.100 & 62.312 & 8847.052 & 6.937 \\
\hline Madagascar & 1988 & 20 & -0.011 & 0.063 & 0.226 & 4.000 & 4.000 & 4.000 & 4.000 & - & 0.110 & - & 41.267 & 18.628 & 300.380 & 22.097 \\
\hline Panama & 1988 & 22 & -0.040 & -0.133 & 0.311 & 2.000 & 2.167 & 2.000 & 2.056 & - & 0.700 & 3.512 & 68.709 & 56.907 & 2837.189 & 5.809 \\
\hline Poland & 1990 & 28 & 0.059 & 1.282 & 0.333 & 3.679 & 1.862 & 4.000 & 3.180 & 5.325 & - & - & 5.361 & 4.448 & & 37.150 \\
\hline Senegal & 1988 & 17 & -0.005 & 0.046 & 0.163 & 3.000 & 2.000 & 2.000 & 2.333 & - & 1.530 & 5.000 & 51.947 & 41.651 & 564.594 & 11.084 \\
\hline Venezuela & 1994 & 28 & 0.018 & 0.104 & 0.319 & 3.000 & 5.000 & 4.000 & 4.000 & 2.635 & -0.200 & 4.702 & 46.149 & 42.189 & 3450.689 & 38.853 \\
\hline Zambia & 1995 & 17 & -0.149 & -0.184 & 0.373 & 2.000 & 2.117 & 1.700 & 1.939 & - & - & - & 64.679 & 9.063 & 492.290 & 84.339 \\
\hline Zimbabwe & 1995 & 25 & -0.031 & -0.066 & 0.327 & 3.000 & 3.750 & 2.000 & 2.917 & - & 0.445 & 5.417 & 40.611 & 20.505 & 634.638 & 14.696 \\
\hline Average & & 21.375 & -0.013 & 0.091 & 0.281 & 3.621 & 3.629 & 3.597 & 3.615 & 5.527 & - & 6.528 & 73.176 & 47.649 & 7384.091 & 47.429 \\
\hline
\end{tabular}




\section{Table VI}

\section{Country-level Averages of Variables Used in Basic Regressions with Change in the EST as the Dependent Variable}

This table shows averages of variables on the national level which we used for regressions with as dependent variable the relative change in industry-level number of establishments (DESTREL) between the crisis and pre-crisis period. We excluded observations whose DESTREL was not in the interval (-1,1). The pre-crisis period is defined as $[t-8, t-3]$ and the crisis period is defined as $[t-1, t+1]$, where $t$ is the first year of the first systemic banking crisis in a country according to Caprio and Klingebiel (2003). DEST is the absolute difference in the EST between the crisis and the pre-crisis period. DESTREL is the relative difference. The corruption, Accountability, and Law and Order institutional indices are on a scale from 0 to 6 , where a higher score indicates a better institution. The institutional index is a composite of all institutional indices. Institutional indices are drawn from ICRG. Credit via Bank (\%) is the domestic credit as a \% of GDP from the WDI. Credit to GDP, GDP per capita, and Inflation are al from the WDI. Corruption (TI) is the perceived corruption index by Transparency International. The Corruption (Beck) measure is from Beck et al. (2000). The external dependence measures are based on Rajan and Zingales (1998).

\begin{tabular}{|c|c|c|c|c|c|c|c|c|c|c|c|c|c|c|c|c|}
\hline \multirow[b]{2}{*}{ Country } & \multirow[b]{2}{*}{$\begin{array}{c}\text { Crisis } \\
\text { date }\end{array}$} & \multirow{2}{*}{$\begin{array}{c}\text { Number } \\
\text { of } \\
\text { Industries } \\
\end{array}$} & \multirow[b]{2}{*}{ DEST } & \multirow[b]{2}{*}{ DESTREL } & \multicolumn{12}{|c|}{ Averages values in pre-crisis period } \\
\hline & & & & & EST & Corruption & Accountability & $\begin{array}{c}\text { Law and } \\
\text { Order }\end{array}$ & $\begin{array}{c}\text { Institutional } \\
\text { index }\end{array}$ & $\begin{array}{l}\text { Corruption } \\
\text { (TI) }\end{array}$ & $\begin{array}{c}\text { Corruption } \\
(\mathrm{KKZ})\end{array}$ & $\begin{array}{c}\text { Corruption } \\
\text { (Beck) }\end{array}$ & $\begin{array}{c}\text { Credit via } \\
\text { Banks (\%) }\end{array}$ & $\begin{array}{l}\text { Credit to } \\
\text { GDP (\%) }\end{array}$ & $\begin{array}{c}\text { GDP per } \\
\text { capita }\end{array}$ & Inflation \\
\hline Algeria & 1990 & 1 & 794.000 & 1.698 & 467.667 & 3.667 & 2.000 & 2.000 & 2.556 & - & - & - & 87.565 & 59.108 & 1796.908 & 10.323 \\
\hline Brazil & 1990 & 11 & -6569.182 & -0.725 & 8126.182 & 3.806 & 3.861 & 3.861 & 3.843 & 3.260 & 0.000 & 6.310 & 51.421 & 44.580 & 3952.198 & 160.165 \\
\hline Bulgaria & 1995 & 8 & 1052.208 & 10.116 & 78.125 & 3.083 & 3.083 & 5.000 & 3.722 & - & - & - & 118.516 & 7.204 & 1586.882 & 338.449 \\
\hline Finland & 1991 & 28 & -31.667 & -0.057 & 252.179 & 6.000 & 6.000 & 6.000 & 6.000 & 9.265 & 1.620 & 10.000 & 58.885 & 61.513 & 23276.260 & 5.657 \\
\hline Hungary & 1991 & 27 & 379.579 & 6.591 & 64.267 & 4.000 & 4.667 & 5.000 & 4.556 & 5.020 & 0.870 & - & 99.867 & 51.375 & 4686.407 & 7.207 \\
\hline Indonesia & 1997 & 26 & 188.329 & 0.499 & 594.037 & 1.600 & 3.000 & 2.833 & 2.478 & 2.685 & -0.760 & - & 43.983 & 44.164 & 827.386 & 8.171 \\
\hline Japan & 1991 & 28 & -252.229 & -0.020 & 15508.460 & 5.000 & 6.000 & 5.000 & 5.333 & 6.810 & 0.950 & 8.512 & 223.709 & 153.530 & 32053.450 & 1.384 \\
\hline Korea & 1997 & 28 & 537.581 & 0.266 & 2644.443 & 4.100 & 2.550 & 2.150 & 2.933 & - & - & 5.298 & 63.100 & 62.312 & 8847.052 & 6.937 \\
\hline Panama & 1988 & 22 & 3.470 & 0.033 & 35.795 & 2.000 & 2.167 & 2.000 & 2.056 & - & 0.110 & 3.512 & 68.709 & 56.907 & 2837.189 & 5.809 \\
\hline Poland & 1990 & 28 & 49.604 & 0.189 & 183.027 & 3.679 & 1.862 & 4.000 & 3.180 & 5.325 & 0.700 & - & 5.361 & 4.448 & & 37.150 \\
\hline Senegal & 1988 & 17 & 1.500 & 0.120 & 7.500 & 3.000 & 2.000 & 2.000 & 2.333 & - & - & 5.000 & 51.947 & 41.651 & 564.594 & 11.084 \\
\hline Sweden & 1991 & 28 & -4.679 & 0.042 & 325.643 & 6.000 & 6.000 & 6.000 & 6.000 & 9.215 & 1.530 & 10.000 & 105.048 & 85.205 & 25455.040 & 6.543 \\
\hline Zambia & 1995 & 17 & 6.000 & 0.314 & 25.353 & 2.000 & 2.117 & 1.700 & 1.939 & - & -0.200 & - & 64.679 & 9.063 & 492.290 & 84.339 \\
\hline$\underline{\text { Zimbabwe }}$ & 1995 & 25 & -5.701 & -0.102 & 41.768 & 3.000 & 3.750 & 2.000 & 2.917 & - & - & 5.417 & 40.611 & 20.505 & 634.638 & 14.696 \\
\hline Average & & 21.467 & -259.613 & 1.257 & 1914.325 & 3.596 & 3.604 & 3.570 & 3.590 & 5.527 & 0.445 & 6.528 & 75.303 & 49.584 & 7890.070 & 49.118 \\
\hline
\end{tabular}




\section{Table VII}

\section{Average Impact of Corruption on Industry-level Price-Cost Margins during a Systemic Banking Crisis}

This table reports OLS regressions. The dependent variable is the relative change in industry-level price-cost margins during a crisis (DPCMREL). The independent variables are the average price-cost margin (PCM) before the crisis and several interaction terms of external dependence of young firms and country-level variables 1) Corruption (ICRG), 2) Law and Order (ICRG), 3) Accountability (ICRG), 4) an average of these indices, and 5) domestic credit via banks to GDP (WDI). For the Corruption index, a higher value means less corruption. $*, * * * * *$ indicate significance at $10 \%$., $5 \%$, and $1 \%$ level, respectively. Heteroskedasticity robust standard errors are reported in parentheses.

\begin{tabular}{|c|c|c|c|c|c|c|c|c|}
\hline & \multicolumn{8}{|c|}{ Relative change of industry-level price-cost margins in crisis (DPCMREL) } \\
\hline & (1) & (2) & (3) & $(4)$ & $(5)$ & $(6)$ & (7) & $(8)$ \\
\hline PCM before crisis & $\begin{array}{l}2.448 \\
(0.433)^{* * *}\end{array}$ & $\begin{array}{l}2.472 \\
(0.433)^{* * *}\end{array}$ & $\begin{array}{l}-2.475 \\
(0.433)^{* * *}\end{array}$ & $\begin{array}{l}2.465 \\
(0.433)^{* * *}\end{array}$ & $\begin{array}{l}-2.453 \\
(0.433)^{* * *}\end{array}$ & $\begin{array}{l}-2.479 \\
(0.434)^{* * *}\end{array}$ & $\begin{array}{l}-2.487 \\
(0.434)^{* * *}\end{array}$ & $\begin{array}{l}-2.472 \\
(0.433)^{* * *}\end{array}$ \\
\hline Ext. dep.*Bank credit & & & & & $\begin{array}{c}0.001 \\
(0.000)^{*}\end{array}$ & $\begin{array}{c}0.001 \\
(0.000)\end{array}$ & $\begin{array}{c}0.001 \\
(0.001)^{*}\end{array}$ & $\begin{array}{c}0.001 \\
(0.001)^{*}\end{array}$ \\
\hline Ext. dep.*Corruption & $\begin{array}{l}-0.036 \\
(0.015)^{* *}\end{array}$ & & & & $\begin{array}{l}-0.052 \\
(0.017)^{* * *}\end{array}$ & & & \\
\hline Ext. dep.*Law and Order & & $\begin{array}{l}-0.013 \\
(0.020)\end{array}$ & & & & $\begin{array}{l}-0.022 \\
(0.021)\end{array}$ & & \\
\hline Ext. dep.*Accountability & & & $\begin{array}{l}-0.013 \\
(0.016)\end{array}$ & & & & $\begin{array}{l}-0.032 \\
(0.020)\end{array}$ & \\
\hline Ext. dep.*Institutional index & & & & $\begin{array}{l}-0.023 \\
(0.019)\end{array}$ & & & & $\begin{array}{l}-0.042 \\
(0.021)^{* *}\end{array}$ \\
\hline Country-specific effects? & Y & Y & $\mathrm{Y}$ & Y & Y & Y & $\mathrm{Y}$ & $\mathrm{Y}$ \\
\hline Industry-specific effects? & $\mathrm{Y}$ & $\mathrm{Y}$ & $\mathrm{Y}$ & $\mathrm{Y}$ & $\mathrm{Y}$ & $\mathrm{Y}$ & $\mathrm{Y}$ & $\mathrm{Y}$ \\
\hline Observations & 316 & 316 & 316 & 316 & 316 & 316 & 316 & 316 \\
\hline R-squared & 0.41 & 0.41 & 0.41 & 0.41 & 0.42 & 0.41 & 0.41 & 0.41 \\
\hline
\end{tabular}




\section{Table VIII}

\section{Average Impact of Corruption on the Industry-Level Number of Establishments during a Systemic Banking Crisis}

This table reports OLS regressions. The dependent variable is the relative change in the industry-level number of establishments during a crisis (DESTREL). The independent variables are the average number of establishments (EST) before the crisis and several interaction terms of external dependence of young firms and country-level variables 1 ) Corruption (ICRG), 2) Law and Order (ICRG), 3) Accountability (ICRG), 4) an average of these indices, and 5) domestic credit via banks to GDP. For the Corruption index, a higher value means less corruption. ${ }^{*}, * * * * *$ indicate significance at $10 \%$., $5 \%$, and $1 \%$ level, respectively. Heteroskedasticity robust standard errors are reported in parentheses.

\begin{tabular}{|c|c|c|c|c|c|c|c|c|}
\hline & \multicolumn{8}{|c|}{ Relative change of industry-level number of establishments in crisis (DESTREL) } \\
\hline & $(1)$ & $(2)$ & $(3)$ & $(4)$ & $(5)$ & $(6)$ & (7) & $(8)$ \\
\hline EST before crisis & $\begin{array}{l}-0.000 \\
(0.000)\end{array}$ & $\begin{array}{l}-0.000 \\
(0.000)\end{array}$ & $\begin{array}{l}-0.000 \\
(0.000)\end{array}$ & $\begin{array}{l}-0.000 \\
(0.000)\end{array}$ & $\begin{array}{l}-0.000 \\
(0.000)\end{array}$ & $\begin{array}{l}-0.000 \\
(0.000)\end{array}$ & $\begin{array}{l}-0.000 \\
(0.000)\end{array}$ & $\begin{array}{l}-0.000 \\
(0.000)\end{array}$ \\
\hline Ext. dep.* Bank credit & & & & & $\begin{array}{l}-0.000 \\
(0.000)\end{array}$ & $\begin{array}{l}-0.000 \\
(0.000)\end{array}$ & $\begin{array}{c}0.000 \\
(0.000)\end{array}$ & $\begin{array}{l}-0.000 \\
(0.000)\end{array}$ \\
\hline Ext. dep.*Corruption & $\begin{array}{l}0.031 \\
(0.015)^{* *}\end{array}$ & & & & $\begin{array}{l}0.037 \\
(0.017)^{* *}\end{array}$ & & & \\
\hline Ext. dep.*Law and Order & & $\begin{array}{c}0.005 \\
(0.018)\end{array}$ & & & & $\begin{array}{c}0.005 \\
(0.019)\end{array}$ & & \\
\hline Ext. dep.*Accountability & & & $\begin{array}{c}0.001 \\
(0.015)\end{array}$ & & & & $\begin{array}{c}0.000 \\
(0.020)\end{array}$ & \\
\hline Ext. dep.*Institutional index & & & & $\begin{array}{c}0.014 \\
(0.017)\end{array}$ & & & & $\begin{array}{c}0.017 \\
(0.020)\end{array}$ \\
\hline Country-specific effects? & Y & Y & Y & $\mathrm{Y}$ & Y & $\mathrm{Y}$ & Y & $\mathrm{Y}$ \\
\hline Industry-specific effects? & $\mathrm{Y}$ & $\mathrm{Y}$ & $\mathrm{Y}$ & $\mathrm{Y}$ & $\mathrm{Y}$ & $\mathrm{Y}$ & $\mathrm{Y}$ & $\mathrm{Y}$ \\
\hline Observations & 260 & 260 & 260 & 260 & 260 & 260 & 260 & 260 \\
\hline R-squared & 0.51 & 0.50 & 0.50 & 0.50 & 0.51 & 0.50 & 0.50 & 0.51 \\
\hline
\end{tabular}




\section{Table IX}

\section{Robustness: Average Impact of Corruption on Industry-Level Price-Cost Margins and the Number of Establishments, Using Different Measures of External Dependence}

This table reports OLS regressions. The dependent variable is either the relative change in industry-level price-cost margins during a crisis (DPCMREL) or the relative change in the number of establishments during a crisis (DESTREL). The independent variables are the average price-cost margin or number of establishments before the crisis and an interaction term of Corruption (ICRG) with several measures of external dependence. For the Corruption index, a higher value means less corruption. *,**.*** indicate significance at $10 \%$., 5\%, and $1 \%$ level, respectively. Heteroskedasticity robust standard errors are reported in parentheses.

\begin{tabular}{|c|c|c|c|c|}
\hline & \multicolumn{2}{|c|}{$\begin{array}{l}\text { Relative change of industry-level price- } \\
\text { cost margins in crisis (DPCMREL) }\end{array}$} & \multicolumn{2}{|c|}{$\begin{array}{l}\text { Relative change of industry-level } \\
\text { number of establishments in crisis } \\
\text { (DESTREL) }\end{array}$} \\
\hline & (1) & (2) & $(3)$ & $(4)$ \\
\hline & All & Young -/- mature & All & Young -/- mature \\
\hline PCM before crisis & $\begin{array}{l}-3.712 \\
(1.161)^{* * *}\end{array}$ & $\begin{array}{l}-2.476 \\
(0.438)^{* * *}\end{array}$ & & \\
\hline Establishments before crisis & & & $\begin{array}{l}-0.000 \\
(0.000)\end{array}$ & $\begin{array}{l}-0.000 \\
(0.000)\end{array}$ \\
\hline Ext. dep.*Corruption & $\begin{array}{c}0.014 \\
(0.054)\end{array}$ & $\begin{array}{l}-0.033 \\
(0.020)\end{array}$ & $\begin{array}{c}0.021 \\
(0.036)\end{array}$ & $\begin{array}{c}0.038 \\
(0.022)^{*}\end{array}$ \\
\hline Country-specific effects? & $\mathrm{Y}$ & Y & Y & $\mathrm{Y}$ \\
\hline Industry-specific effects? & $\mathrm{Y}$ & $\mathrm{Y}$ & $\mathrm{Y}$ & $\mathrm{Y}$ \\
\hline Observations & 340 & 303 & 278 & 246 \\
\hline R-squared & 0.39 & 0.41 & 0.45 & 0.53 \\
\hline
\end{tabular}


Table X

Robustness: Average Impact of Corruption on Industry-level Price Cost-Margins and Number of Establishments, Controlling for Domestic Credit

The dependent variable is either the relative change in industry-level price-cost margins during a crisis (DPCMREL) or the relative change in the number of establishments during a crisis (DESTREL). The independent variables are the average price-cost margin before the crisis and the average number of establishments before the crisis, respectively. The common independent variables are several interaction terms of external dependence of young firms and country-level variables 1) corruption (ICRG), 2) law and order (ICRG), 3) accountability $(\mathrm{ICRG}), 4)$ an average of these indices, and 5) domestic credit via banks to GDP (WDI). For the Corruption index, a higher value means less corruption. One percent tails of the DESTREL distribution in the basic sample have been dropped from the analysis to reduce the effect of outliers. ${ }^{*}, * *$. $* * *$ indicate significance at $10 \%$., $5 \%$, and $1 \%$ level, respectively. Heteroskedasticity robust standard errors are reported in parentheses.

\begin{tabular}{|c|c|c|c|c|c|c|c|c|}
\hline & \multicolumn{4}{|c|}{$\begin{array}{l}\text { Relative change of industry-level price-cost margins in crisis } \\
\text { (DPCMREL) }\end{array}$} & \multicolumn{4}{|c|}{$\begin{array}{c}\text { Relative change of industry-level number of establishments in } \\
\text { crisis (DESTREL) }\end{array}$} \\
\hline & $(1)$ & $(2)$ & (3) & (4) & $(5)$ & $(6)$ & $(7)$ & $(8)$ \\
\hline PCM before crisis & $\begin{array}{l}-2.431 \\
(0.433)^{* * *}\end{array}$ & $\begin{array}{l}-2.467 \\
(0.433)^{* * *}\end{array}$ & $\begin{array}{l}-2.468 \\
(0.433)^{* * *}\end{array}$ & $\begin{array}{l}-2.452 \\
(0.432)^{* * *}\end{array}$ & & & & \\
\hline Establishments before crisis & & & & & $\begin{array}{l}-0.000 \\
(0.000)\end{array}$ & $\begin{array}{l}-0.000 \\
(0.000)^{*}\end{array}$ & $\begin{array}{l}-0.000 \\
(0.000)^{*}\end{array}$ & $\begin{array}{l}-0.000 \\
(0.000)^{*}\end{array}$ \\
\hline Ext. dep.*Domestic credit & $\begin{array}{l}0.002 \\
(0.001)^{* *}\end{array}$ & $\begin{array}{c}0.001 \\
(0.001)\end{array}$ & $\begin{array}{c}0.001 \\
(0.001)\end{array}$ & $\begin{array}{c}0.001 \\
(0.001)^{*}\end{array}$ & $\begin{array}{c}0.000 \\
(0.001)\end{array}$ & $\begin{array}{c}0.001 \\
(0.001)\end{array}$ & $\begin{array}{c}0.001 \\
(0.001)\end{array}$ & $\begin{array}{c}0.001 \\
(0.001)\end{array}$ \\
\hline Ext. dep. *Corruption & $\begin{array}{l}-0.057 \\
(0.019)^{* * *}\end{array}$ & & & & $\begin{array}{l}0.033 \\
(0.016)^{* *}\end{array}$ & & & \\
\hline Ext. dep.*Law and Order & & $\begin{array}{l}-0.023 \\
(0.023)\end{array}$ & & & & $\begin{array}{l}-0.003 \\
(0.019)\end{array}$ & & \\
\hline Ext. dep.*Accountability & & & $\begin{array}{l}-0.034 \\
(0.024)\end{array}$ & & & & $\begin{array}{l}-0.016 \\
(0.020)\end{array}$ & \\
\hline Ext. dep. ${ }^{*}$ Institutional index & & & & $\begin{array}{l}-0.045 \\
(0.025)^{*}\end{array}$ & & & & $\begin{array}{c}0.006 \\
(0.020)\end{array}$ \\
\hline Country-specific effects? & $\mathrm{Y}$ & Y & Y & Y & $\mathrm{Y}$ & $\mathrm{Y}$ & $\mathrm{Y}$ & Y \\
\hline Industry-specific effects? & $\mathrm{Y}$ & $\mathrm{Y}$ & $\mathrm{Y}$ & $\mathrm{Y}$ & $\mathrm{Y}$ & $\mathrm{Y}$ & $\mathrm{Y}$ & $\mathrm{Y}$ \\
\hline Observations & 316 & 316 & 316 & 316 & 257 & 257 & 257 & 257 \\
\hline R-squared & 0.42 & 0.41 & 0.41 & 0.42 & 0.54 & 0.54 & 0.54 & 0.54 \\
\hline
\end{tabular}




\section{Table XI}

\section{Robustness: Using other Corruption Indices}

The dependent variable is either the relative change in industry-level price-cost margins during a crisis (DPCMREL) or the relative change in the number of establishments during a crisis (DESTREL). The independent variables are the average PCM before the crisis and the average number of establishments before the crisis, respectively. Common independent variables are an interaction of the external dependence of young firms and domestic credit via banks to GDP and an interaction of the external dependence of young firms and Corruption (TI). Corruption (TI) is the average of the Corruption Perceptions Index over the years 1995, 1996, and 1997 by Transparency International. One percent tails of the distribution of DPCMREL and DESTREL in the basic sample have been dropped from the analysis to reduce the effect of extreme values. For all Corruption indices, a higher value means less corruption. *, **.*** indicate significance at $10 \%$., 5\%, and $1 \%$ level, respectively. Heteroskedasticity robust standard errors are reported in parentheses.

Panel A:

\begin{tabular}{|c|c|c|c|c|c|c|}
\hline & \multicolumn{6}{|c|}{ Relative change of industry-level price-cost margins in crisis (DPCMREL) } \\
\hline & (1) & $(2)$ & (3) & (4) & $(5)$ & (6) \\
\hline PCM before crisis & $\begin{array}{l}-2.161 \\
(0.616)^{* * *}\end{array}$ & $\begin{array}{l}-2.603 \\
(0.600)^{* * *}\end{array}$ & $\begin{array}{l}-2.483 \\
(0.513) * * *\end{array}$ & $\begin{array}{l}2.172 \\
(0.620)^{* * *}\end{array}$ & $\begin{array}{l}-2.607 \\
(0.603)^{* * *}\end{array}$ & $\begin{array}{l}-2.483 \\
(0.515)^{* * *}\end{array}$ \\
\hline Ext. dep.*Domestic credit & & & & $\begin{array}{c}0.001 \\
(0.000)^{*}\end{array}$ & $\begin{array}{c}0.000 \\
(0.000)\end{array}$ & $\begin{array}{c}0.000 \\
(0.000)\end{array}$ \\
\hline Ext. dep. ${ }^{*}$ Corruption (Beck) & $\begin{array}{l}-0.017 \\
(0.012)\end{array}$ & & & $\begin{array}{l}-0.024 \\
(0.011)^{* *}\end{array}$ & & \\
\hline Ext. dep. ${ }^{*}$ Corruption (TI) & & $\begin{array}{l}-0.017 \\
(0.010)^{*}\end{array}$ & & & $\begin{array}{l}-0.020 \\
(0.011)^{*}\end{array}$ & \\
\hline Ext. dep. ${ }^{*}$ Corruption $(\mathrm{KKZ})$ & & & $\begin{array}{l}-0.063 \\
(0.035)^{*}\end{array}$ & & & $\begin{array}{l}-0.070 \\
(0.035)^{* *}\end{array}$ \\
\hline Country-specific effects? & Y & $\mathrm{Y}$ & Y & Y & Y & Y \\
\hline Industry-specific effects? & $\mathrm{Y}$ & $\mathrm{Y}$ & $\mathrm{Y}$ & $\mathrm{Y}$ & $\mathrm{Y}$ & $\mathrm{Y}$ \\
\hline Observations & 200 & 189 & 225 & 200 & 189 & 225 \\
\hline R-squared & 0.46 & 0.46 & 0.48 & 0.46 & 0.46 & 0.48 \\
\hline \multicolumn{7}{|l|}{ Panel B: } \\
\hline & \multicolumn{6}{|c|}{ Relative change of industry-level EST in crisis (DESTREL) } \\
\hline & (1) & $(2)$ & $(3)$ & $(4)$ & $(5)$ & (6) \\
\hline Establishments before crisis & $\begin{array}{c}0.000 \\
(0.000)\end{array}$ & $\begin{array}{l}-0.000 \\
(0.000)\end{array}$ & $\begin{array}{l}-0.000 \\
(0.000)\end{array}$ & $\begin{array}{c}0.000 \\
(0.000)\end{array}$ & $\begin{array}{l}-0.000 \\
(0.000)\end{array}$ & $\begin{array}{l}-0.000 \\
(0.000)\end{array}$ \\
\hline Ext. dep. ${ }^{*}$ Domestic credit & & & & $\begin{array}{l}-0.000 \\
(0.000)\end{array}$ & $\begin{array}{l}-0.000 \\
(0.000)\end{array}$ & $\begin{array}{l}-0.000 \\
(0.000)\end{array}$ \\
\hline Ext. dep. ${ }^{*}$ Corruption (Beck) & $\begin{array}{l}-0.001 \\
(0.012)\end{array}$ & & & $\begin{array}{c}0.004 \\
(0.013)\end{array}$ & & \\
\hline Ext. dep. *Corruption (TI) & & $\begin{array}{l}0.020 \\
(0.007)^{* * *}\end{array}$ & & & $\begin{array}{l}0.023 \\
(0.007)^{* * *}\end{array}$ & \\
\hline Ext. dep. ${ }^{*}$ Corruption $(\mathrm{KKZ})$ & & & $\begin{array}{l}0.067 \\
(0.025)^{* * *}\end{array}$ & & & $\begin{array}{l}0.072 \\
(0.026)^{* * *}\end{array}$ \\
\hline Country-specific effects? & $\mathrm{Y}$ & Y & $\mathrm{Y}$ & Y & Y & $\mathrm{Y}$ \\
\hline Industry-specific effects? & $\mathrm{Y}$ & $\mathrm{Y}$ & $\mathrm{Y}$ & $\mathrm{Y}$ & $\mathrm{Y}$ & $\mathrm{Y}$ \\
\hline Observations & 189 & 163 & 208 & 189 & 163 & 208 \\
\hline R-squared & 0.53 & 0.74 & 0.56 & 0.53 & 0.74 & 0.56 \\
\hline
\end{tabular}




\section{Table XII}

\section{Robustness: Average Impact of Corruption on the Industry-level Price-Cost Margins, Controlling for Country Variables}

The dependent variable is either the relative change in industry-level price-cost margins (PCMs) during a crisis (DPCMREL) or the relative change in the number of institutions during a crisis (DESTREL). The independent variables are the average PCM (number of establishments) before the crisis and several interaction terms of external dependence of young firms and country-level variables 1) corruption (ICRG), 2) Domestic credit to GDP (WDI), 3) a corruption dummy, and 4) Domestic credit via banks to GDP (WDI). For the Corruption index, a higher value means less corruption. Further independent variables are the Institutional Index (ICRG), Inflation (WDI), and GDP per capita (WDI). *, **.*** indicate significance at $10 \%$, 5\%, and $1 \%$ level, respectively. Heteroskedasticity robust standard errors are reported in parentheses.

\begin{tabular}{|c|c|c|c|c|c|c|}
\hline & \multicolumn{3}{|c|}{$\begin{array}{l}\text { Relative change of industry-level price-cost margins in crisis } \\
\text { (DPCMREL) }\end{array}$} & \multicolumn{3}{|c|}{$\begin{array}{l}\text { Relative change of industry-level number of establishments } \\
\text { in crisis (DESTREL) }\end{array}$} \\
\hline & $(1)$ & $(2)$ & (3) & $(4)$ & (5) & $(6)$ \\
\hline PCM before crisis & $\begin{array}{l}-1.916 \\
(0.421)^{* * *}\end{array}$ & $\begin{array}{l}-2.016 \\
(0.414)^{* * *}\end{array}$ & $\begin{array}{l}-2.468 \\
(0.436) * * *\end{array}$ & & & \\
\hline $\begin{array}{l}\text { Establishments } \\
\text { before crisis }\end{array}$ & & & & $\begin{array}{l}-0.000 \\
(0.000)^{*}\end{array}$ & $\begin{array}{l}-0.000 \\
(0.000)\end{array}$ & $\begin{array}{l}-0.000 \\
(0.000)\end{array}$ \\
\hline $\begin{array}{l}\text { Ext. } \\
\text { dep. } * \text { Corruption }\end{array}$ & $\begin{array}{l}-0.050 \\
(0.018)^{* * *}\end{array}$ & $\begin{array}{l}-0.054 \\
(0.017)^{* * *}\end{array}$ & & $\begin{array}{c}0.036 \\
(0.019) *\end{array}$ & $\begin{array}{c}0.044 \\
(0.019)^{* *}\end{array}$ & \\
\hline $\begin{array}{l}\text { Ext. } \\
\text { dep. }{ }^{*} \text { Corruption } \\
\text { dummy } \\
1 \text { if above median, } 0 \\
\text { otherwise }\end{array}$ & & & $\begin{array}{l}-0.049 \\
(0.065)\end{array}$ & & & $\begin{array}{c}0.150 \\
(0.049)^{* * *}\end{array}$ \\
\hline $\begin{array}{l}\text { Ext. dep.*Bank } \\
\text { credit }\end{array}$ & $\begin{array}{c}0.001 \\
(0.001)\end{array}$ & $\begin{array}{c}0.001 \\
(0.001)\end{array}$ & & $\begin{array}{l}-0.000 \\
(0.000)\end{array}$ & $\begin{array}{l}-0.001 \\
(0.000)^{*}\end{array}$ & \\
\hline Corruption & $\begin{array}{c}0.009 \\
(0.020)\end{array}$ & $\begin{array}{l}0.095 \\
(0.039)^{* *}\end{array}$ & & $\begin{array}{l}-0.069 \\
(0.017) * * *\end{array}$ & $\begin{array}{l}-0.163 \\
(0.060)^{* * *}\end{array}$ & \\
\hline Bank credit & $\begin{array}{l}-0.001 \\
(0.001)^{* * *}\end{array}$ & $\begin{array}{l}-0.004 \\
(0.001)^{* * *}\end{array}$ & & $\begin{array}{l}0.001 \\
(0.000)^{*}\end{array}$ & $\begin{array}{c}0.002 \\
(0.002)\end{array}$ & \\
\hline Total credit & & $\begin{array}{l}0.012 \\
(0.002)^{* * *}\end{array}$ & & & $\begin{array}{l}-0.004 \\
(0.002)^{* *}\end{array}$ & \\
\hline Inflation & & $\begin{array}{l}0.002 \\
(0.001)^{* * *}\end{array}$ & & & $\begin{array}{l}-0.003 \\
(0.001)^{* * *}\end{array}$ & \\
\hline GDP per capita & & $\begin{array}{l}-0.000 \\
(0.000)^{* * *}\end{array}$ & & & $\begin{array}{c}0.000 \\
(0.000)\end{array}$ & \\
\hline $\begin{array}{l}\text { Country-specific } \\
\text { effects? }\end{array}$ & $\mathrm{N}$ & $\mathrm{N}$ & $\mathrm{Y}$ & $\mathrm{N}$ & $\mathrm{N}$ & $\mathrm{Y}$ \\
\hline $\begin{array}{l}\text { Industry-specific } \\
\text { effects? }\end{array}$ & $\mathrm{Y}$ & $\mathrm{Y}$ & $\mathrm{Y}$ & $\mathrm{Y}$ & $\mathrm{Y}$ & $\mathrm{Y}$ \\
\hline Observations & 316 & 291 & 316 & 257 & 232 & 260 \\
\hline R-squared & 0.27 & 0.35 & 0.41 & 0.13 & 0.31 & 0.52 \\
\hline
\end{tabular}




\section{Table XIII}

\section{Robustness: Average Impact of Corruption on the Relative Change in Industry-level Price-Cost Margins, Controlling for a Quadratic Interaction Term and Using Quantile Regressions}

This table reports OLS and quantile regressions. The dependent variable is the relative change in industry-level price-cost margins (PCM) during a crisis (DPCMREL). The independent variables are the average PCM before the crisis and several interaction terms of external dependence of young firms and country-level variables 1) corruption (ICRG), 2) and corruption squared (ICRG). For the Corruption index, a higher value means less corruption. For Model (1)-(3), the one percent tails of the distribution of DPCMREL have been dropped. $* * * . * * *$ indicate significance at $10 \%$., 5\%, and $1 \%$ level, respectively. Heteroskedasticity robust standard errors are reported in parentheses.

\begin{tabular}{|c|c|c|c|c|c|c|}
\hline & \multicolumn{6}{|c|}{ Relative change of industry-level number of price-cost margins in crisis (DPCMREL) } \\
\hline & \multicolumn{3}{|c|}{ OLS } & \multicolumn{3}{|c|}{ Quantile regressions } \\
\hline & (1) & $(2)$ & (3) & (4) & $(5)$ & (6) \\
\hline & High cor. & Low cor. & Full sample & $\mathrm{Q}(.1)$ & $\mathrm{Q}(.5)$ & $\mathrm{Q}(.9)$ \\
\hline PCM before crisis & $\begin{array}{l}-1.798 \\
(0.381)^{* * *}\end{array}$ & $\begin{array}{l}-1.777 \\
(0.430)^{* * *}\end{array}$ & $\begin{array}{l}-2.141 \\
(0.355)^{* * *}\end{array}$ & $\begin{array}{l}-0.473 \\
(0.000)^{* * *}\end{array}$ & $\begin{array}{l}-1.552 \\
(0.000)^{* * *}\end{array}$ & $\begin{array}{l}-3.169 \\
(0.092)^{* * *}\end{array}$ \\
\hline Ext. dep.*Corruption & $\begin{array}{l}-0.119 \\
(0.057)^{* *}\end{array}$ & $\begin{array}{c}0.050 \\
(0.036)\end{array}$ & $\begin{array}{l}0.248 \\
(0.110)^{* *}\end{array}$ & $\begin{array}{l}-0.031 \\
(0.000) * * *\end{array}$ & $\begin{array}{l}-0.035 \\
(0.000)^{* * *}\end{array}$ & $\begin{array}{l}-0.063 \\
(0.004)^{* * *}\end{array}$ \\
\hline Ext. dep. ${ }^{*}$ Corruption^${ }^{\wedge}$ & & & $\begin{array}{l}0.027 \\
(0.013)^{* *}\end{array}$ & & & \\
\hline Country-specific effects? & Y & Y & Y & Y & Y & Y \\
\hline Industry-specific effects? & $\mathrm{Y}$ & $\mathrm{Y}$ & $\mathrm{Y}$ & $\mathrm{Y}$ & $\mathrm{Y}$ & $\mathrm{Y}$ \\
\hline Observations & 155 & 154 & 309 & 316 & 316 & 316 \\
\hline (Pseudo) R-squared & 0.59 & 0.61 & 0.53 & 0.42 & 0.33 & 0.46 \\
\hline
\end{tabular}




\section{Table XIV}

\section{Robustness: Average Impact of Corruption on Industry-level Price Cost-Margins and Number of Establishments, Controlling for Terms of Trade Changes}

The dependent variable is either the relative change in industry-level price-cost margins (PCMs) during a crisis (DPCMREL) or the relative change in the number of institutions during a crisis (DESTREL). The independent variables are the average PCM (number of establishments) before the crisis and several interaction terms of external dependence of young firms and country-level variables 1) corruption (ICRG), 2) Domestic credit to GDP (WDI), 3) a corruption dummy, 4) Domestic credit via banks to GDP (WDI), and 5) change in the terms of trade (WDI). For the Corruption index, a higher value means less corruption. Further independent variables are the Institutional Index (ICRG), Inflation (WDI), and GDP per capita (WDI). *, **. *** indicate significance at 10\%., 5\%, and 1\% level, respectively. Heteroskedasticity robust standard errors are reported in parentheses.

\begin{tabular}{|c|c|c|}
\hline & $\begin{array}{l}\text { Relative change of } \\
\text { industry-level price-cost } \\
\text { margins in crisis } \\
\text { (DPCMREL) }\end{array}$ & $\begin{array}{l}\text { Relative change of } \\
\text { industry-level number } \\
\text { of establishments in } \\
\text { crisis (DESTREL) }\end{array}$ \\
\hline & $(1)$ & $(2)$ \\
\hline PCM before crisis & $\begin{array}{l}-2.273 \\
(0.454)^{* * *}\end{array}$ & \\
\hline $\begin{array}{l}\text { Establishments before } \\
\text { crisis }\end{array}$ & & $\begin{array}{l}-0.000 \\
(0.000)\end{array}$ \\
\hline Ext. dep.*Corruption & $\begin{array}{l}-0.055 \\
(0.018)^{* * *}\end{array}$ & $\begin{array}{c}0.033 \\
(0.019)^{*}\end{array}$ \\
\hline Ext. dep.*Bank credit & $\begin{array}{c}0.001 \\
(0.001)\end{array}$ & $\begin{array}{l}-0.000 \\
(0.000)\end{array}$ \\
\hline Terms of trade (change) & $\begin{array}{l}-0.612 \\
(0.372)\end{array}$ & $\begin{array}{l}1.615 \\
(0.365)^{* * *}\end{array}$ \\
\hline Corruption & $\begin{array}{c}0.065 \\
(0.044)\end{array}$ & $\begin{array}{l}-0.279 \\
(0.072)^{* * *}\end{array}$ \\
\hline Bank credit & $\begin{array}{l}-0.005 \\
(0.001)^{* * *}\end{array}$ & $\begin{array}{l}0.003 \\
(0.002)^{* *}\end{array}$ \\
\hline Total credit & $\begin{array}{l}0.013 \\
(0.002)^{* * *}\end{array}$ & $\begin{array}{l}-0.014 \\
(0.002)^{* * *}\end{array}$ \\
\hline Inflation & $\begin{array}{l}0.002 \\
(0.001)^{* * *}\end{array}$ & $\begin{array}{l}-0.000 \\
(0.001)\end{array}$ \\
\hline GDP per capita & $\begin{array}{l}-0.000 \\
(0.000)^{* * *}\end{array}$ & $\begin{array}{l}0.000 \\
(0.000)^{* * *}\end{array}$ \\
\hline Country-specific effects? & $\mathrm{N}$ & $\mathrm{N}$ \\
\hline Industry-specific effects? & $\mathrm{Y}$ & $\mathrm{Y}$ \\
\hline Observations & 265 & 210 \\
\hline R-squared & 0.37 & 0.46 \\
\hline
\end{tabular}




\section{Table XV}

\section{Robustness: Average Impact of Corruption on the Relative Change of the Price-Cost Margins and the Number of Establishments by Industry-Informativeness}

The dependent variable is either the relative change in industry-level price-cost margins (PCMs) during a crisis (DPCMREL) or the relative change in the number of institutions during a crisis (DESTREL). The independent variables are the average price-cost margin (PCM) (number of establishments) before the crisis and two interaction terms of industry informativeness with Corruption (ICRG) and external dependence of young firms and Domestic credit via banks to GDP (WDI). For the Corruption index, a higher value means less corruption. The information variable is taken from Huang (2005); a higher value means more informative. One percent tails of the DESTREL distribution in the basic sample have been dropped from the analysis to reduce the effect of extreme values. $*, * * . * * *$ indicate significance at $10 \%$., $5 \%$, and $1 \%$ level, respectively. Heteroskedasticity robust standard errors are reported in parentheses.

\begin{tabular}{lcccc}
\hline & \multicolumn{2}{c}{$\begin{array}{c}\text { Relative change of industry- } \\
\text { level price-cost margins in crisis } \\
\text { (DPCMREL) }\end{array}$} & $\begin{array}{l}\text { Relative change of industry- } \\
\text { level number of establishments } \\
\text { in crisis (DESTREL) }\end{array}$ \\
\cline { 2 - 5 } & $(1)$ & $(2)$ & $(3)$ & $(4)$ \\
PCM before crisis & -3.503 & -2.640 & & \\
& $(1.178)^{* * *}$ & $(0.442)^{* * *}$ & & \\
Establishments before crisis & & & -0.000 & -0.000 \\
& & & $(0.000)$ & $(0.000)$ \\
Ext. dep.*Bank credit & & 0.001 & & -0.000 \\
& & $(0.000)^{*}$ & & $(0.000)$ \\
Info*Corruption & 0.047 & 0.056 & -0.016 & -0.024 \\
& $(0.017)^{* * *}$ & $(0.016)^{* * *}$ & $(0.014)$ & $(0.014)^{*}$ \\
Country-specific effects? & $\mathrm{Y}$ & $\mathrm{Y}$ & $\mathrm{Y}$ & $\mathrm{Y}$ \\
Industry-specific effects? & $\mathrm{Y}$ & $\mathrm{Y}$ & $\mathrm{Y}$ & $\mathrm{Y}$ \\
Observations & 328 & 316 & 269 & 257 \\
R-squared & 0.41 & 0.43 & 0.44 & 0.54 \\
\hline
\end{tabular}

